\title{
Luminescence dating of the Volochysk section - a key Podolian loess site (Ukraine)
}

\author{
Stanisław FEDOROWICZ1 ${ }^{1}$, Maria ŁANCZONT², Przemysław MROCZEK ${ }^{2, *}$, Andriy BOGUCKI ${ }^{3}$, \\ Karol STANDZIKOWSKI ${ }^{2}$, Piotr MOSKA ${ }^{4}$, Jarosław KUSIAK ${ }^{2}$ and Andrzej BLUSZCZ ${ }^{4}$
}

1 University of Gdańsk, Department of Geomorphology and Quaternary Geology, Institute of Geography, Bażyńskiego 4, 80-950 Gdańsk, Poland

2 Maria Curie-Skłodowska University, Faculty of Earth Sciences and Spatial Management, al. Kraśnicka 2d, 20-718 Lublin, Poland

3 Ivan Franko National University, Department of Geomorphology and Palaeogeography, Doroshenka 41, 79000 Lviv, Ukraine

4 Silesian University of Technology, Institute of Physics - Center for Science and Education, Konarskiego 22b, 44-100 Gliwice, Poland

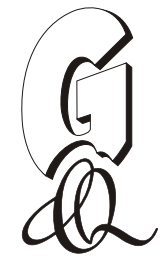

Fedorowicz, S., Łanczont, M., Mroczek, P., Bogucki, A., Standzikowski, K., Moska, P., Kusiak, J., Bluszcz, A., 2018. Luminescence dating of the Volochysk section - a key Podolian loess site (Ukraine). Geological Quarterly, 62 (3): 729-744, doi: 10.7306/gq.1436

Associate editor: Wojciech Granoszewski

The Volochysk site belongs to important and unique loess sites in the Podolia Upland (W Ukraine) because it contains relatively well-developed loess deposits representing the last and penultimate glacial cycles. This loess-palaeosol sequence consists of pedocomplex S1 (MIS 5) developed on loess L2, and loess L1 (MIS 4-2) with the palaeosols of lower, interstadial rank. In this sequence, different periglacial structures were found, including the largest ones of ice-wedge cast type. Different quartz and polymineral fractions separated from the samples collected in the Volochysk site were dated using luminescence methods (SAR OSL, post-IR IRSL and TL) in three Polish luminescence laboratories in Gdańsk, Gliwice and Lublin. In total, 69 luminescence dating results were obtained for 18 samples. The methodological and research aims were to carry out mutual verification of the obtained dating results as well as to analyse and interpret the differences between them, and to determine the age of distinguished deposit layers and the period of cryogenic activities. The luminescence dates of the sediments, which were deposited during MIS 2, 3 and 4, corresponded fairly well to the ages attributed to these stages. They also indicate the age of periglacial phenomena. However, the TL dates were generally older than the OSL ones, especially those obtained for the sediments deposited during MIS 5 and 6 . The results of the research of the Volochysk sequence were compared with those obtained in past years for the loess deposits of the Volhynian Upland (north of Podolia) during similar inter-laboratory analyses conducted to determine their age. The results of OSL datings of the older deposits (MIS 5 and MIS 6) are underestimated irrespective of the used method, and the type (quartz, polymineral) and size of grains. Numerous attempts were made to explain this phenomenon, which, however, give no answer. It was only found that this underestimation corresponded to the equivalent dose value of $\sim 150 \mathrm{~Gy}$.

Key words: loess-palaeosol sequence, luminescence dating, quartz, polymineral fractions, Podolia.

\section{INTRODUCTION}

Ukrainian loess deposits are situated near the northern boundary of the central part of the European loess province (Fig. 1A). A considerable part of this province occurs in Ukraine where several loess regions with vast and thick loess covers can be distinguished. In the western part of Ukraine, these are the Volhynian and Podolian uplands (Fig. 1B). A regional strati-

\footnotetext{
* Corresponding author, e-mail: loess@poczta.umcs.lublin.pl
}

Received: February 19, 2018; May 17, 2017; first published online: November 13, 2018 graphic scheme of loess deposits in the western part of Ukraine was established by Bogucki (1972, 1986, 1987), and then developed in detail by Bogucki and Łanczont (2002). The luminescence age of the Volhynian loess was recently studied in detail, based on the Boyanychi and Korshiv key profiles (Kusiak et al., 2012; Fedorowicz et al., 2013) that are also very important for stratigraphy of the Middle and Upper Pleistocene loess in Central Europe (Bogucki and Łanczont, 2011). Loess from the Boyanychi profile was TL dated in the Gdańsk and Lublin laboratories (Kusiak et al., 2012), while the Korshiv profile was sampled for TL and OSL dating, and the same samples were dated in three Polish laboratories - in Gdańsk, Gliwice and Lublin.

The same group of authors undertook also work on determining the TL age of loess in the southern and central parts of the Podolia Upland, in the catchments of the Seret, Zbruch and 

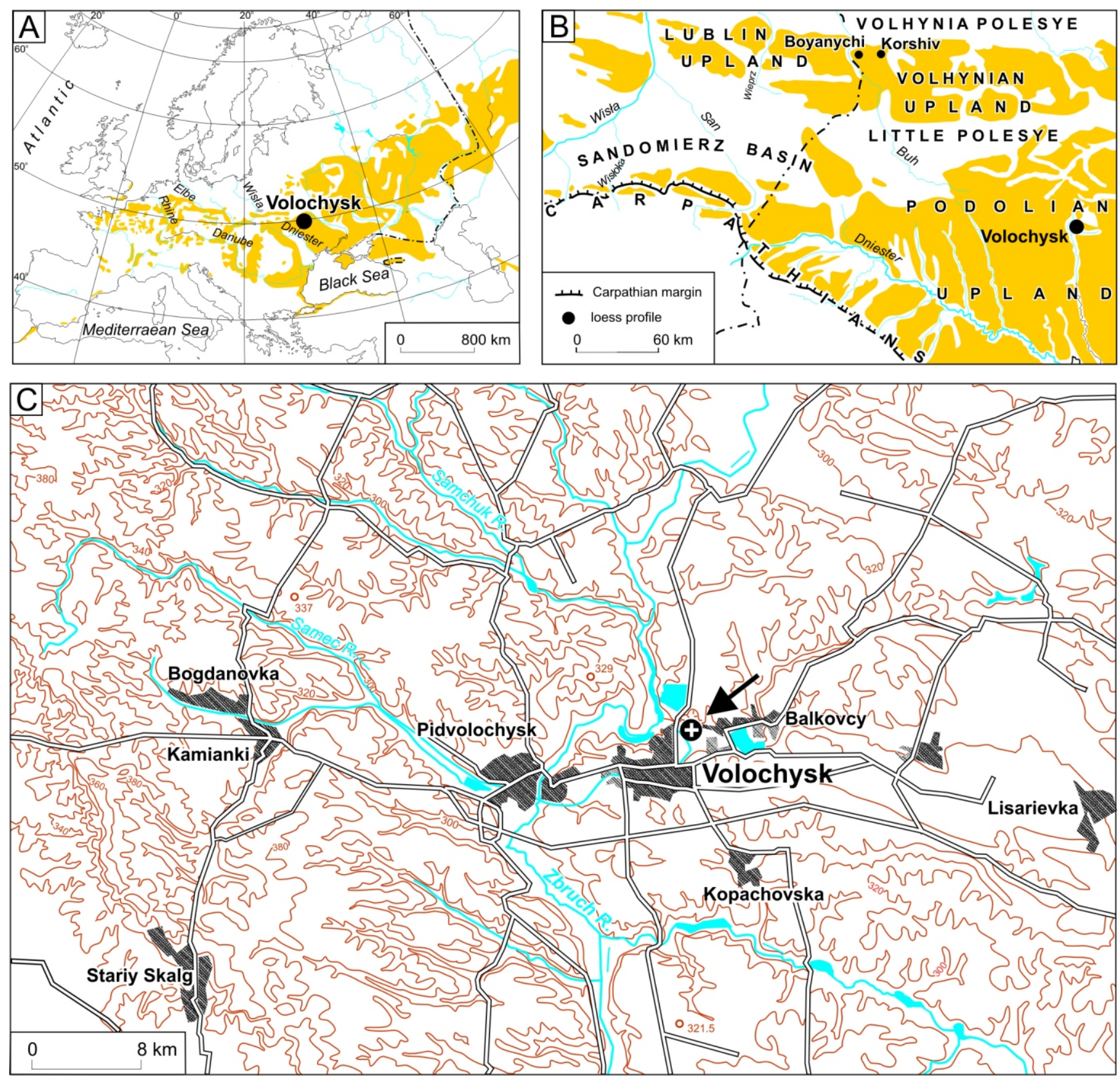

Fig. 1. Location of the Volochysk loess profile in relation to: A - loess distribution in Europe; B - loess distribution in the western part of Ukraine; C - topographic sketch

Prut rivers (Bogucki et al., 2009; Kusiak et al., 2012; Łanczont et al., 2011; Łanczont and Madeyska, 2015). The Podolian loess deposits are characterized by predominance of older (Middle and Lower Pleistocene) loess, while loess representing the last glacial cycle is found rarely and its profiles are incomplete. This gap in understanding of the younger part of the palaeoclimatic history of the Podolia Upland can be filled by the results obtained for the loess profile exposed in the brickyard at Volochysk on the Zbruch River, which is situated in the northern part of the upland. In this profile the upper part of the loess cover is represented by relatively well-developed younger loess with stratigraphic diversity similar to that typical of the Volhynian loess deposits, which occur $\sim 35 \mathrm{~km}$ to the north. In order to determine the age of loess and soil layers distinguished in the Volochysk profile, the methods of TL, OSL and IRSL dating were used. At the same time, the relationship between the obtained results and the grain size and type (quartz or polymineral fraction) of dated samples was analyzed. An attempt was also made to assess the usefulness of grain-size analyses for the selection of grain fractions used for luminescence dating. Such attempts were taken earlier for interglacial aquatic sediments (Fedorowicz and Gaigalas, 2010). An additional purpose was to determine the time of formation and destruction of large periglacial wedge structures, which form a cryogenic key horizon in the Volhynian and Podolian loess profiles.

The main purposes of the study were:

- to determine the age of Late Pleistocene loess and soil horizons in Podolia, in comparison with the age ranges of warm and cold periods in the oxygen isotope time scale (Cohen and Gibbard, 2012), based on the inter-laboratory dating results;

- to make an interregional (Volhynia, Podolia) correlation between the successive loess- and soil-forming stages of the Late Pleistocene in the western part of the East European loess province; 
- to use a quite large collection of dating results of the Volhynian and Podolian loess deposits, obtained in several laboratories using different procedures, to draw conclusions about dating methods.

\section{VOLOCHYSK PROFILE - KEY LOESS SITE OF THE NORTHERN PODOLIAN LOESS COVER}

The Volochysk site is one of a few loess profiles of the northern Podolia area. This profile $\left(26^{\circ} 14.5^{\prime} \mathrm{E} ; 49^{\circ} 33^{\prime} \mathrm{N}\right)$ is situated in the western part of the Khmelnytskyi Plateau (a subregion of the Podolian Upland, western Ukraine), on the left side of the valley of the Zbruch River, which is a tributary of the Dniester River (Fig. 1B, C). The site is located in the eastern outskirts of the town of Volochysk, in a pit where loess is exploited for a local brickyard. The pit is located in the upper part of loess plateau slope (Figs. $1 \mathrm{C}$ and $2 \mathrm{~A}$ ). The profile top is at $284 \mathrm{~m}$ a.s.l., while the watershed part of the plateau reaches $305 \mathrm{~m}$ a.s.l. The valley bottom is at $275 \mathrm{~m}$ a.s.l. (Fig. 1C).

In the Volochysk site the near-surface part of the loess cover consists of two loess units ( $\mathrm{L} 1$ and $\mathrm{L} 2$ according to Kukla, 1987) accumulated during the last two glacial cycles, which are separated by the Horokhiv pedocomplex (S1), correlated with MIS 5. The younger loess L1 contains horizons of lower stratigraphic rank, i.e. the Dubno soil unit (MIS 3) and the interphase Krasyliv horizon which is a buried active permafrost layer (within the younger part of MIS 2). This loess-soil sequence contains also a rich set of different and uneven-aged periglacial deformations, with the most noticeable horizon of large ice-wedge casts being unequivocal evidence of permafrost occurrence and connected with the Krasyliv horizon. This is a system of cryogenic structures of the youngest generation found in the Late Pleistocene loess deposits of the East European loess province. These structures belong certainly to the largest ones (Bogucki, 1990). The ice-wedge casts form polygons at least $30 \mathrm{~m}$ in diameter.

Loess deposits in the Volochysk site were investigated in two profiles. Exposure I (Fig. 2A, B) was selected because it represented a quite complete sequence of layers, not much disturbed by periglacial phenomena. Exposure II (Fig. 2A, F) contained a large, $>4 \mathrm{~m}$ high, ice-wedge cast (Fig. 2C-E). Only the top part of loess L2 was investigated, which directly underlies soil S1 ( 1 m thick). In the studied exposures, the thickness of loess L2 reaches $4-5 \mathrm{~m}$ (Fig. 2C), but its bottom is not visible. Lithology (Table 1) of the profile was described in the field by A. Bogucki and M. Łanczont in 2010 (Fig. 2B). The profile was sampled for luminescence dating and physico-chemical analyses. The sampling sites are marked with the symbol "W-" (Table 1).

\section{PHYSICO-CHEMICAL ANALYSIS}

Main particle-size parameters were determined for all collected samples (18) in Lublin (Fig. 3), while calcium carbonate content was measured in Gdańsk (Fedorowicz et al., 2012; Matla, 2012). Particle-size distribution was determined by a laser diffraction method (with the use of the Malvern Mastersizer 2000 Hydro G). Samples were prepared according to the procedure proposed by Antoine et al. (2013). The particle-size distribution varies in the vertical profile, but two fractions (16-32 $\mu \mathrm{m}$ and $32-50 \mu \mathrm{m})$ constitute $\sim 25-33 \%$ of each sample. The occurrence of coarser grains $(0.5-0.2 \mathrm{~mm})$ is notable, as they are found only in the Dubno pedocomplex (samples W-6 and W-5) and Krasyliv horizon (sample W-1) - 3.5, 2.8 and 6.2\%, respec- tively. The calculated granulometric indices (vide Folk and Ward, 1957) are typical of loess deposits, i.e. poor sorting (1.48-2.36) and positive skewness (0.01-0.37), except for the mentioned soil horizons. The mean grain size in the studied sequence ranges from 5.45 to 6.19 phi.

In respect of particle-size distribution, the material filling the ice-wedge cast is quite uniform. The contents of individual fractions are similar in four analysed samples (the differences generally do not exceed $2 \%$ ).

The whole profile is carbonate, with the highest $\mathrm{CaCO}_{3}$ content directly below the Krasyliv horizon (>15\%) and in the top part of $L 2(\sim 25 \%)$, and the lowest content in the Dubno (5-6\%) and Horokhiv (<2\%) units (Fig. 3).

\section{DATING METHODS}

In order to determine the luminescence age of deposits, 14 samples were taken from the undisturbed part of exposure I. All the distinguished soil and loess units were sampled. Each loess layer of considerable thickness $(>0.5 \mathrm{~m})$ was sampled at 2-3 sites. In exposure II, four samples were taken along the vertical section of the ice-wedge cast (Fig. 2E). Material from all the selected sampling sites was taken using three probes at the same time. In case of samples for the Gliwice and Lublin laboratories, metal tubes, $40 \mathrm{~cm}$ long and $5 \mathrm{~cm}$ in diameter, were used. Samples taken for TL dating in the Gdańsk laboratory were cube-shaped blocks with the sides of $10 \mathrm{~cm}$. Mean moisture values measured for loess deposits range from 15 to $25 \%$ (Aitken, 1998). The engineering geology investigations of the Podolian loesses (Bogucki et al., 2014) showed the following values of natural moisture: loess L1 - 10-17\%, Dubno unit $17-19 \%$, Horokhiv unit $-15-23 \%$, loess L2 - 12-15\%, and infillings of ice-wedge casts $-10-16 \%$. Therefore, in this work, we used the moisture value of $15 \%$ in the calculations (Gdańsk and Lublin laboratory).

The samples for luminescence dating were collected in 2010. They were dated using the TL, OSL and IRSL methods in three Polish laboratories (in Gdańsk, Gliwice and Lublin). In total, 69 luminescence dating results were obtained for different grain fractions. Dating was carried out in two stages. In 2011, the laboratories applied their analytical procedures. In Lublin, the OSL method (post-IR IRSL technique) was used for dating of the 45-56 $\mu \mathrm{m}$ fraction of polymineral grains. Particle-size determination by laser diffraction indicated that the content of this fraction in the samples ranged from 4.1 to $7.6 \%$ (the average was $5.7 \%$ ). In Gliwice, the SAR OSL method was used for dating of the 90-125 $\mu \mathrm{m}$ fraction of quartz grains. The content of this fraction was $0.5-3.4 \%$ (the average was $1.4 \%$ ). In Gdańsk, the TL method was used for dating of the $80-100 \mu \mathrm{m}$ quartz fraction, the content of which ranged from 0.5 to $1.4 \%$ (the average was $1.1 \%$ ). The second stage of dating was in 2014. In Gliwice, the OSL method (post-IR IRSL technique) was used for dating of the 4-11 $\mu \mathrm{m}$ polymineral fraction (12.5-23.8\%; the average $18.6 \%$ ). In Lublin, the SAR OSL method was used for dating of the $45-63 \mu \mathrm{m}$ fraction of quartz grains (5.6-10.6\%; the average $7.9 \%$ ), and it was the same material which was dated in the Gdańsk laboratory in 2011 (Appendix 1*).

\section{GLIWICE LABORATORY}

All samples were dried in the laboratory. The Canberra high-resolution gamma spectrometer with an HPGe detector was used to determine the contents of $\mathrm{U}$, Th and $\mathrm{K}$ in the sam- 


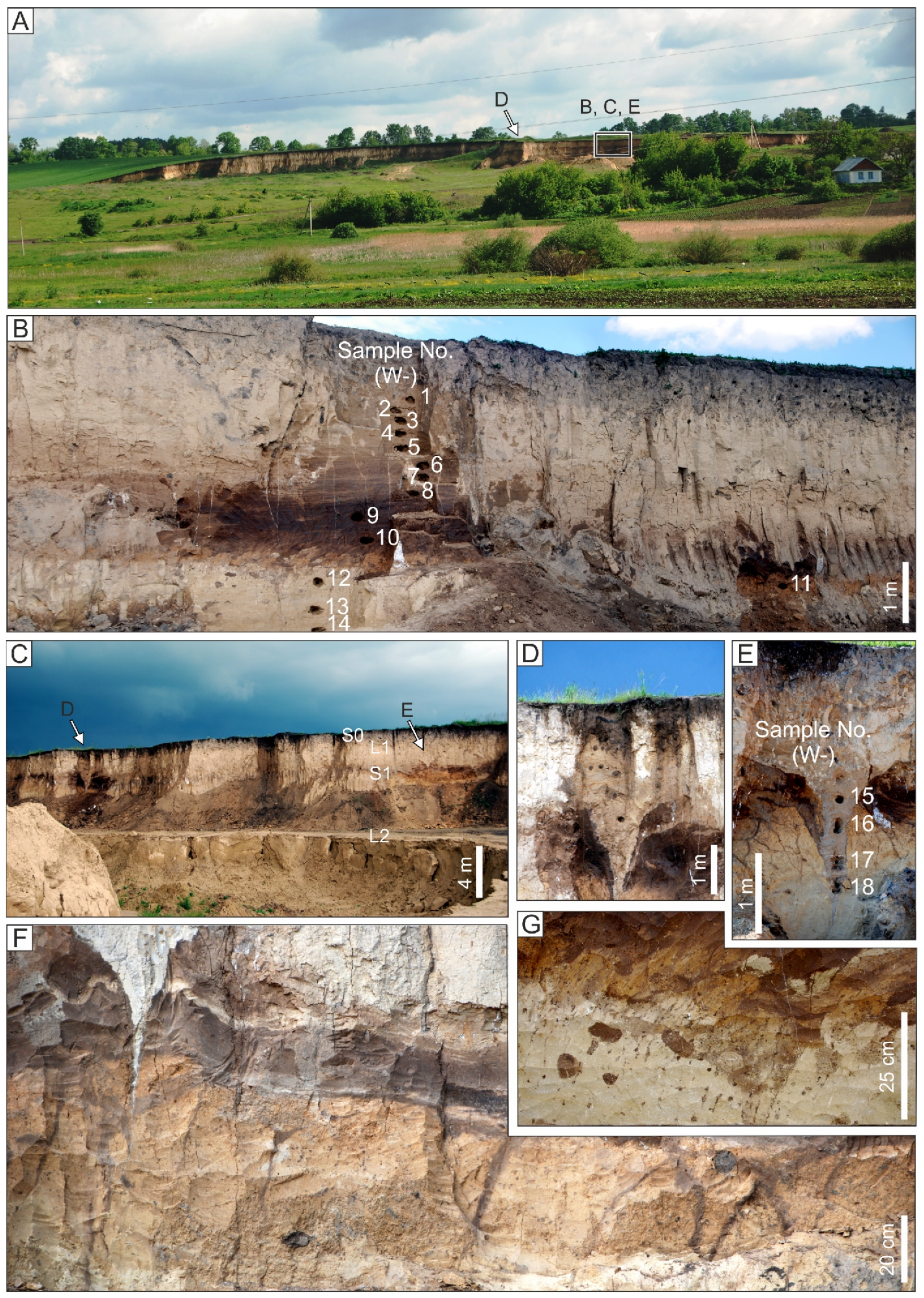


Litho- and pedological characteristics and stratigraphic interpretation of the Volochysk profile

\begin{tabular}{|c|c|}
\hline $\begin{array}{c}\text { Depth } \\
\text { [m] }\end{array}$ & Characteristic \\
\hline $0-0.9$ & $\begin{array}{l}\text { Recent soil of chernozem type (SO) } \\
\text { Humus horizon (A) of chernozem, the bottom part } 0.4 \mathrm{~m} \text { thick, carbonate sandy silt, grey and dark grey, with distinct } \\
\text { crumb structure, with krotovinas and small faunal channels filled with soil material; } \mathrm{HCl}^{+} . \mathrm{Gradual}^{-} \text {transition. } \\
\text { Horizon Bk, sandy silt, dark yellow, porous, with numerous pseudomycelia and carbonate concretions up to } 4-5 \mathrm{~cm} \\
\text { in diameter, in the bottom part more intensely gleyed and enriched with iron compounds, with exceptionally numer- } \\
\text { ous krotovinas filled with dark humus material within the material of horizon Bk, which creates spotty appearance of } \\
\text { horizon. Distinct boundary, uneven, in many places distinguishable due to the concentration of krotovinas (5 cm in } \\
\text { diameter) and small faunal channels ( } 2 \mathrm{~cm} \text { in diameter). }\end{array}$ \\
\hline \multicolumn{2}{|r|}{ Loess L1 } \\
\hline $0.9-1.5$ & $\begin{array}{l}\text { Krasyliv horizon - sandy silt, carbonate, yellowish, compact, with a dense net of pseudomycelia, with numerous } \\
\text { carbonate concretions up to } 3 \mathrm{~cm} \text { in diameter, with soft black Mn-Fe nodules up to } 3 \text { mm in diameter. Distinct bound- } \\
\text { ary, accentuated by enrichment with iron compounds. } \\
\qquad \mathbf{W}-1-1.1 \mathrm{~m} ; \mathbf{W}-\mathbf{2}-\mathbf{1 . 4} \mathbf{m}\end{array}$ \\
\hline $1.5-1.9$ & $\begin{array}{l}\text { Homogeneous carbonate loess, yellowish-grey, in places gleyed and enriched with iron compounds, with black and } \\
\text { rust-coloured Mn-Fe nodules that are less numerous than in the Krasyliv horizon, with pseudomycelia, and single } \\
\text { narrow fissures filled with carbonates. Distinct boundary, change of colour and deposit compactness. } \\
\qquad \mathbf{W}-\mathbf{3}-\mathbf{1 . 6} \mathrm{m} ; \mathbf{W}-\mathbf{- 4}-\mathbf{1 . 8} \mathrm{m}\end{array}$ \\
\hline $1.9-2.5$ & $\begin{array}{l}\text { Dubno interstadial pedocomplex, disturbed by solifluction, especially in the upper and lower parts, but locally } \\
\text { along the whole thickness. } \\
\text { Humus horizon, } 0.35 \mathrm{~m} \text { thick }(1.9-2.25 \mathrm{~m}) \text {, carbonate clayey silt, bluish-greyish or grey, stratified in places, compact, } \\
\text { with numerous fibrous pseudomycelia, with spots of iron compounds, and Liesegang ring-type structures up to } \\
1.5 \mathrm{~cm} \text { in diameter. Sub-vertical narrow }(0.5 \mathrm{~cm}) \text { fissures, encrusted with carbonate, } 1.5-2 \mathrm{~m} \text { deep, occur at regular } \\
\text { intervals (every } 0.5-0.7 \mathrm{~m}) \text { and run downwards from the surface of horizon A. } \\
\text { W-5 - } 2.05 \mathrm{~m} \\
\text { Horizon Bw, } 0.25 \text { m thick }(2.25-2.5 \mathrm{~m}) \text {, carbonate clayey silt, yellow-brown, indistinctly stratified in places, quite ho- } \\
\text { mogeneous, compact, with numerous soft black Mn-Fe nodules. Distinct boundary. } \\
\text { W-6-2.35 m }\end{array}$ \\
\hline $2.5-2.7$ & $\begin{array}{l}\text { Carbonate loess, fawn with bluish tint, homogeneous, indistinctly stratified in places, with soft black Mn-Fe nodules } \\
\text { up to } 3 \mathrm{~mm} \text { in diameter; } \mathrm{HCl}^{+} \text {. Distinct boundary. } \\
\qquad \begin{array}{l}\mathbf{W}-\mathbf{7}-\mathbf{2 . 6} \mathbf{~ m}\end{array}\end{array}$ \\
\hline $2.7-3.0$ & $\begin{array}{l}\text { Solifluction horizon - composed of dark yellow loess and light brown humus material from the underlying Horokhiv } \\
\text { soil, carbonate, with pseudomycelia, and small Mn-Fe nodules. Distinct, wavy boundary. } \\
\qquad \mathbf{W}-\mathbf{8}-\mathbf{2 . 8 0} \mathbf{m}\end{array}$ \\
\hline \multicolumn{2}{|r|}{ Fossil pedocomplex S1, Horokhiv s.I. } \\
\hline $3.0-4.0$ & 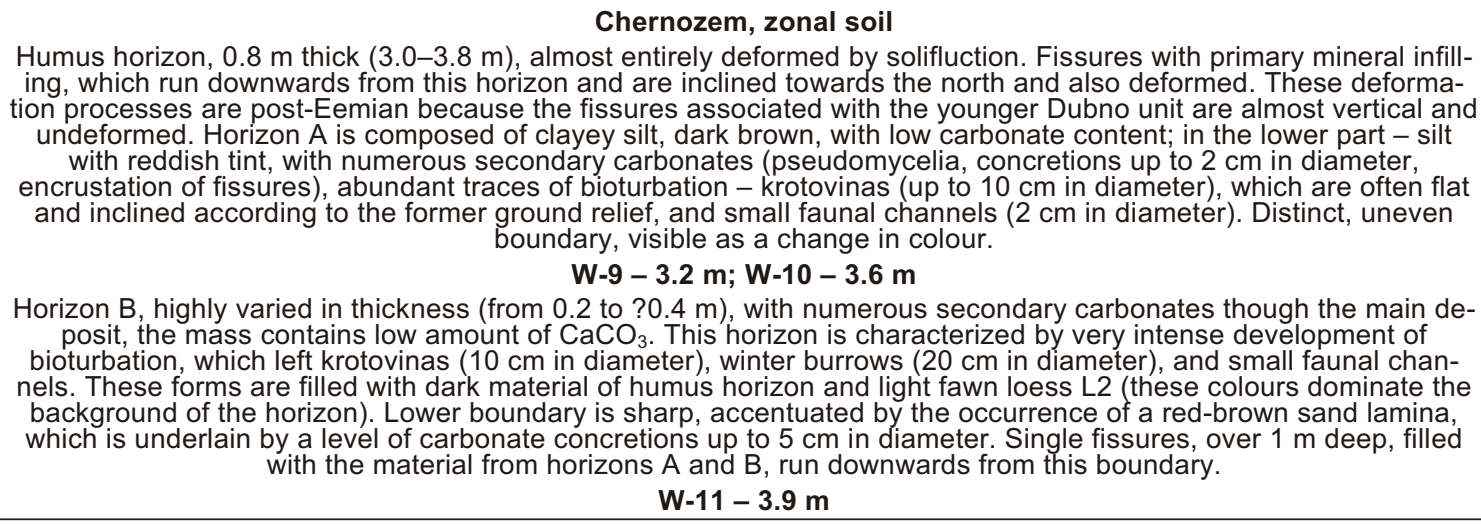 \\
\hline \multicolumn{2}{|r|}{ Loess L2 } \\
\hline $4.0-4.8$ & $\begin{array}{l}\text { Horizon } \mathrm{Ck} \text { - carbonate sandy silt, light fawn, strongly enriched with secondary carbonates (pseudomycelia, concre- } \\
\text { tions } 4 \mathrm{~cm} \text { in diameter, powdery carbonates), with numerous krotovinas and winter burrows up to } 12 \mathrm{~cm} \text { in diameter, } \\
\text { and small faunal channels up to } 3 \mathrm{~cm} \text { in diameter. Locally, these forms are distinctly concentrated. } \\
\qquad \mathbf{W}-\mathbf{1 2}-\mathbf{4 . 2} \mathrm{m} ; \mathbf{W}-\mathbf{1 3}-\mathbf{4 . 7} \mathrm{m}\end{array}$ \\
\hline $4.8-5.1$ & $\begin{array}{l}\text { Carbonate loess, but with lower content of carbonates than in horizon Ck, krotovinas are absent. } \\
\qquad \mathbf{W}-14-5.0 \mathrm{~m}\end{array}$ \\
\hline
\end{tabular}

Fig. 2. Volochysk loess profile: A - view of the pit from the south; B - main exposure I; C - loess-soil sequence S0-L2; D, E, F examples of ice-wedge casts; G - bioturbation forms (krotovinas) in the Horokhiv soil 


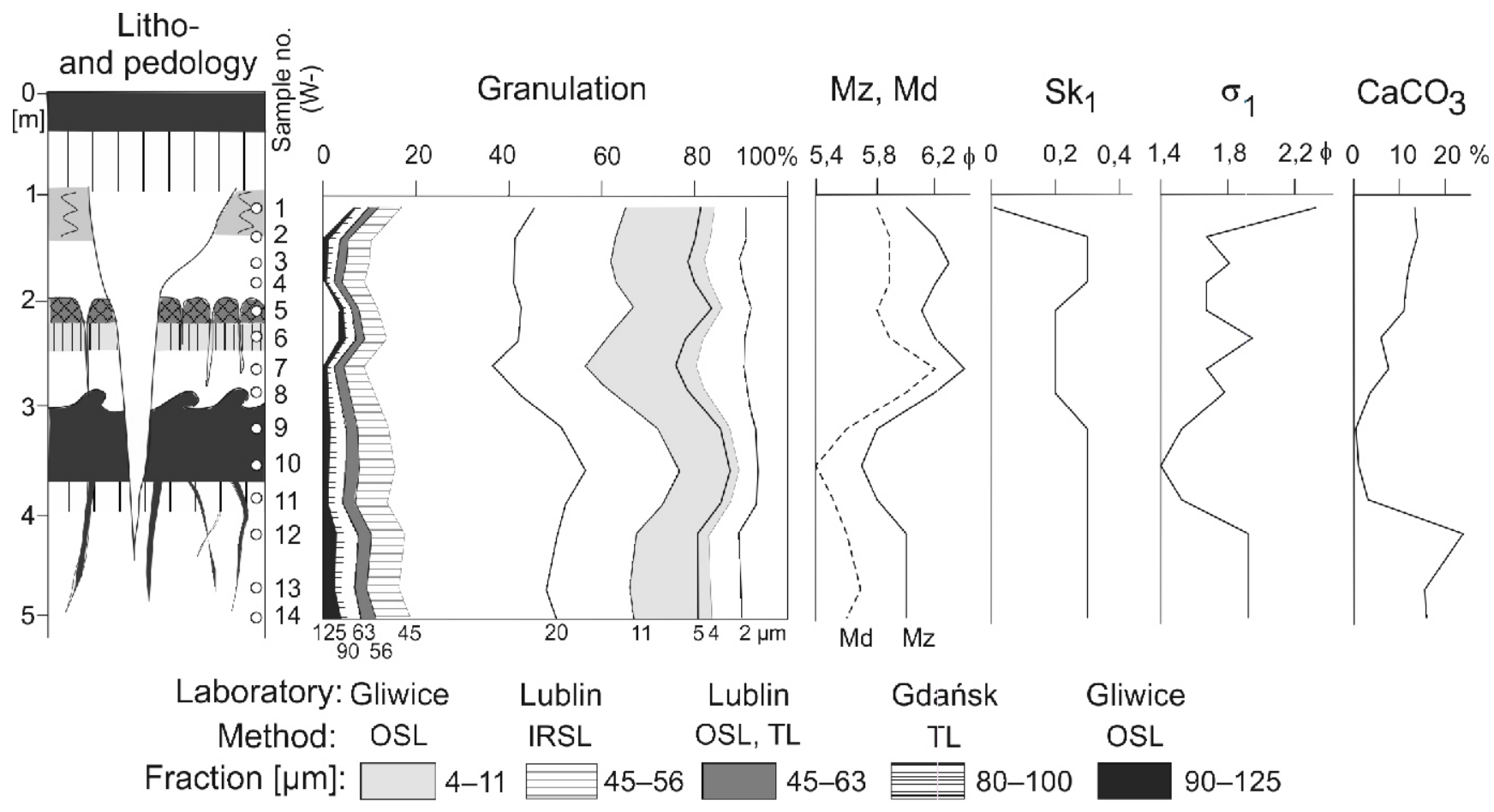

Fig. 3. Lithology of the profile, particle-size distribution of loess (with the fractions selected for luminescence dating), granulometric indices after Folk and Ward (1957), and carbonate content

ples (Appendix 2). The measurements were performed for $600-800 \mathrm{~g}$ samples placed in Marinelli beakers. The IAEA standards RGU, RGTh and RGK were used to determine the activities of the isotopes present in the sediment. The dose rates $d_{r}$ were calculated using the conversion factors of Adamiec and Aitken (1998).

The cosmic radiation dose $\left(d_{c}\right)$ to the site follows the calculations suggested by Prescott and Hutton (1994). Based on these data, the average dose rates for the 90-125 $\mu \mathrm{m}$ grain-size fraction were calculated.

For the OSL measurements, coarse grains of quartz $(90-125 \mu \mathrm{m})$ were extracted from the sediment samples by routine treatment with $20 \%$ hydrochloric acid $(\mathrm{HCl})$ and $20 \%$ hydrogen peroxide $\left(\mathrm{H}_{2} \mathrm{O}_{2}\right)$, followed by double sieving before and after $60 \mathrm{~min}$ of concentrated hydrofluoric acid (HF) treatment. Heavy liquid (sodium polytungstate solutions) was used to obtain a pure quartz extract.

For the post-IR IRSL measurements, polymineral fine grain samples (4-11 $\mu \mathrm{m})$ were extracted from the sediment samples. The sediment was first treated with $20 \%$ hydrochloric acid $(\mathrm{HCl})$ and $20 \%$ hydrogen peroxide $\left(\mathrm{H}_{2} \mathrm{O}_{2}\right)$. Subsequently, the sediment was rinsed with deionized water. After drying, the sediment was suspended in alcohol, and grains of desired diameter range were extracted by sedimentation. First, larger grains were deposited by leaving the suspension in a $7 \mathrm{~cm}$ high column of alcohol for $11 \mathrm{~min}$. The suspension was then transferred to another test tube and left for another $11 \mathrm{~min}$. This step was repeated 4 times. In the last step, the solution above the settled material was decanted after 12 hours leaving the required fraction. The cleaned polymineral grains were suspended in $50 \mathrm{ml}$ of acetone, and $2 \mathrm{ml}$ of the suspension was pipetted to a flat-bottom tube with a stainless-steel disk placed at the bottom. The grains settled on the disk surface and, after evaporation of the alcohol, the disks with a mono-layer of fine polymineral grains were obtained. The OSL measurements were performed using an automated Daybreak 2200 TL/OSL reader (Bortolot, 2000). Multi-grain single aliquots, each containing $\sim 1 \mathrm{mg}$ of grains attached to stainless steel discs by means of Silkospray, were used. For blue light stimulation, an array of blue LEDs $(470 \pm 4 \mathrm{~nm})$ delivering $\sim 60 \mathrm{~mW} / \mathrm{cm}^{2}$ at the sample position was used. For the laboratory irradiations, a calibrated ${ }^{90} \mathrm{Sr} /{ }^{90} \mathrm{Y}$ beta source integrated with the reader delivering a dose rate of $\sim 5.27 \mathrm{~Gy} / \mathrm{min}$ was used. The equivalent doses $\left(d_{e}\right)$ were determined using the single-aliquot regenerative dose (SAR) protocol (Murray and Wintle, 2000). The OSL SAR protocol, which was used in our measurements, contained the following steps:

1. Irradiation with the regenerative beta dose $d_{i}$,

2. Pre-heat at the temperature of $260^{\circ} \mathrm{C}$ for $10 \mathrm{sec}$,

3. Blue light stimulation at the temperature $125^{\circ} \mathrm{C}$ for $100 \mathrm{sec}$,

4. Irradiation with test dose $d_{t}(10 \%$ of the natural dose, but not less than $5 \mathrm{~Gy}$ ),

5. Cut-heat at the temperature of $220^{\circ} \mathrm{C}$,

6. Blue light stimulation at the temperature $125^{\circ} \mathrm{C}$ for $100 \mathrm{sec}$.

For all SAR procedures, a 0 Gy regenerative dose step was added to check the recuperation of the OSL signal (Murray and Wintle, 2000). The recuperation for all measured aliquots was $<5 \%$. In addition, an IRSL measurement was performed to check the purity of the obtained quartz. For the polymineral fine grains samples, equivalent doses were determined using a post-IR IRSL protocol (Thiel et al., 2011), as follows:

1. Irradiation with the regenerative beta dose $d_{i}$,

2. Pre-heat at the temperature $320^{\circ} \mathrm{C}$ for $60 \mathrm{sec}$,

3. IR stimulation at the temperature $50^{\circ} \mathrm{C}$ for $200 \mathrm{sec}$,

4. IR stimulation at the temperature $290^{\circ} \mathrm{C}$ for $200 \mathrm{sec}$,

5. Irradiation with the test dose $d_{t}(10 \%$ of the natural dose, but not less than $5 \mathrm{~Gy}$ ),

6. Pre-heat at the temperature $320^{\circ} \mathrm{C}$ for $60 \mathrm{sec}$,

7. IR stimulation at the temperature $50^{\circ} \mathrm{C}$ for $200 \mathrm{sec}$,

8. IR stimulation at the temperature $290^{\circ} \mathrm{C}$ for $200 \mathrm{sec}$,

9. IR stimulation at the temperature $325^{\circ} \mathrm{C}$ for $100 \mathrm{sec}$.

Intensities measured in steps 4 and 8 were used for equivalent dose determination. For equivalent dose calculation, the 


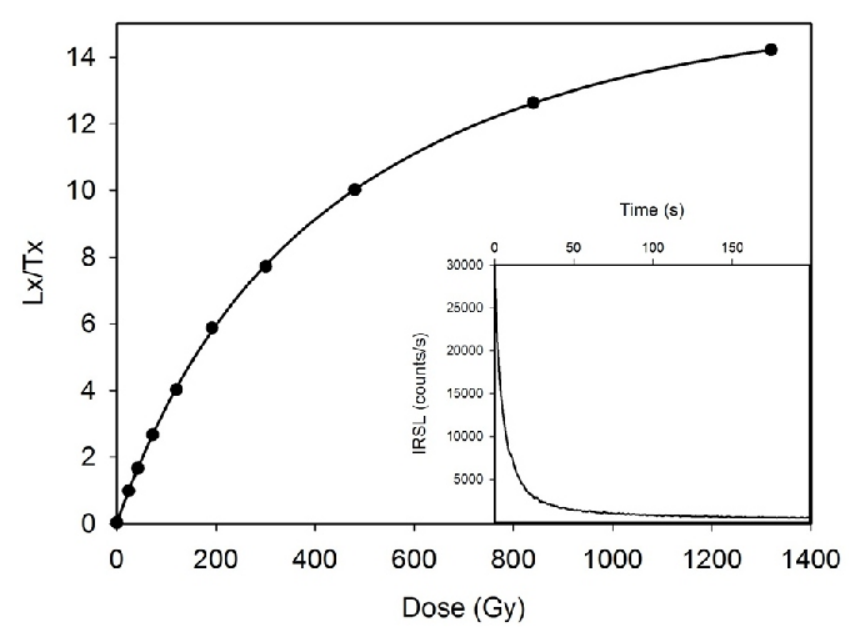

Fig. 4. Full dose response curves for polymineral fraction (post-IR IRSL), along with a typical decay curve (inset)

Response curve ftted best to a double saturating exponential (sample W-12, Gliwice laboratory)

first second of the signal was used, and the background was estimated on the basis of the last 10 second of the OSL decay curve. The protocols were coded as data-taking scripts and executed under Daybreak First Light Software (Bortolot and Bluszcz, 2003).

During our investigation, the full growth curves (up to $1100 \mathrm{~Gy}$ ) for sample W-12 were built. An example of such a full growth curve is shown in Figure 4, together with a typical decay curve. Growth curves in this case were fitted with a double saturating exponential function to determine $d_{\mathrm{e}}$.

\section{LUBLIN LABORATORY}

Samples of $600-800 \mathrm{~g}$ were dried in the laboratory, put into Marinelli beakers, and placed in a protective chamber of a three-channel gamma-ray spectrometer of MAZAR-95 and MAZAR-01 types (produced by Polon IZOT Warszawa). The concentrations of $\mathrm{Ra}$, Th and $\mathrm{K}$ isotopes were measured (Appendicies 3 and 4). Each sample was analysed from 40 to 100 times in the spectrometer, and each measurement lasted $2000 \mathrm{~s}$. The concentrations of ${ }^{226} \mathrm{Ra},{ }^{228} \mathrm{Th}$ and ${ }^{40} \mathrm{~K}$ were converted into dose rates - alfa $\left(d_{\alpha}\right)$, beta $\left(d_{\beta}\right)$ and gamma $\left(d_{\gamma}\right)$ - using the conversion factors of Adamiec and Aitken (1998). Average values were calculated for the $45-56 \mu \mathrm{m}$ grain-size fraction for post-IR IRSL and 45-63 $\mu \mathrm{m}$ for OSL. The cosmic radiation dose $\left(d_{c}\right)$ to the sampling site was calculated according to Prescott and Hutton (1994). Dose rate $\left(d_{r}\right)$ is a sum of doses from alpha, beta, gamma and cosmic radiation (Appendicies 3 and 4).

Each sample was sieved to obtain the $45-56 \mu \mathrm{m}$ fraction for post-IR IRSL and 45-63 $\mu \mathrm{m}$ fraction for OSL. In both cases, grain fractions were treated with $10 \% \mathrm{HCl}$ for 24 hours. After each phase of treatment, grains were washed with distilled water several times. Grains prepared in such a way were dried at $50^{\circ} \mathrm{C}$ for 24 hours.

The OSL and post-IR IRSL measurement cycles and the recording of glow curves (Fig. 5) were performed using the RISO TL/OSL DA-20 reader. For OSL measurements, the reader was equipped with a filter U340, and the sample was stimulated by the blue LED $(470 \mathrm{~nm})$ delivering $\sim 60 \mathrm{~mW} / \mathrm{cm}^{2}$ at the sample. The sample was irradiated using the beta ${ }^{90} \mathrm{Sr} /{ }^{90} \mathrm{Y}$ source. For post-IR IRSL measurements, the Schott BG-39 and Corning
7-59 filters (320-480 $\mathrm{nm}$ ) were used. The sample was irradiated using the IR LED $(870 \mathrm{~nm})$ delivering $135 \mathrm{~mW} / \mathrm{cm}^{2}$. In the case of OSL method, the equivalent dose $\left(d_{e}\right)$ was determined using the SAR procedure (Murray and Wintle, 2000). The OSL SAR protocol, which was used in our measurements, contained the following steps:

1. Give dose, $d_{i}$,

2. Pre-heat $260^{\circ} \mathrm{C}$ for $10 \mathrm{sec}$,

3. Optically stimulate for $100 \mathrm{sec}$ at $125^{\circ} \mathrm{C}$

4. Give test dose $d_{t,}$

5. Heat to $220^{\circ} \mathrm{C}$ for $0 \mathrm{sec}$,

6. Optically stimulate for $100 \mathrm{sec}$ at $125^{\circ} \mathrm{C}$

7. Return to 1.

The post-IR IRSL measurements were conducted according to the SAR procedure (Thomsen et al., 2008; Thiel et al., 2011) containing the following steps:

1. Give dose, $d_{i}$,

2. Pre-heat $320^{\circ} \mathrm{C}$ for $60 \mathrm{sec}$,

3. IRSL measurement, $200 \mathrm{sec}$ at $50^{\circ} \mathrm{C}$,

4. IRSL measurement, $200 \mathrm{sec}$ at $290^{\circ} \mathrm{C}$,

5. Give test dose $d_{t}$

6. Pre-heat $320^{\circ} \mathrm{C}$ for $60 \mathrm{sec}$,

7. IRSL measurement, $200 \mathrm{sec}$ at $50^{\circ} \mathrm{C}$

8. IRSL measurement, $200 \mathrm{sec}$ at $290^{\circ} \mathrm{C}$

9. IRSL measurement, $200 \mathrm{~s}$ at $325^{\circ} \mathrm{C}$,

10. Return to 1.

\section{GDAŃSK LABORATORY}

Samples of $600-800 \mathrm{~g}$ were dried in the laboratory, put into Marinelli beakers, and placed in a protective chamber of a three-channel gamma-ray spectrometer of MAZAR-95 type (produced by Polon IZOT Warszawa). The concentrations of $\mathrm{Ra}$, Th and $\mathrm{K}$ isotopes were measured. Each sample was analysed 40 times in the spectometer, and each measurement lasted $2000 \mathrm{sec}$ (Appendix 5). The concentrations of ${ }^{226} \mathrm{Ra}$, ${ }^{228} \mathrm{Th}$ and ${ }^{40} \mathrm{~K}$ were converted into dose rates - alfa $\left(d_{\alpha}\right)$, beta $\left(d_{\beta}\right)$ and gamma $\left(d_{\gamma}\right)$ - using the conversion factors of Adamiec and Aitken (1998). Average values were calculated for the 80-100 $\mu \mathrm{m}$ grain-size fraction. The cosmic radiation dose $\left(d_{c}\right)$ to the sampling site was calculated according to Prescott and Hutton (1994). Dose rate $\left(d_{r}\right)$ is a sum of doses from alpha, beta, gamma and cosmic radiation.

Each sample was sieved to obtain the $80-100 \mu \mathrm{m}$ fraction. It was treated with $10 \% \mathrm{HCl}$ for 24 hours, and then with $2 \%$ $\mathrm{NaOH}$ for 24 hours, and with $40 \% \mathrm{HF}$ for 45 minutes (Bluszcz, 2000). After each phase of treatment, grains were washed with distilled water.

After this preparation, the material was dried and divided into two portions. The first one was used to measure the natural t-hermoluminescence (TLN). The remaining portion was optically bleached by the exposure to UV light (NTL+UV) for $\sim 12$ hours until the grains reached the so-called residual thermoluminescence. For this purpose, the lamp Osram UItra-Vitalux $300 \mathrm{~W}$ was used.

Equivalent dose $\left(d_{e}\right)$ was determined by the recording of glow curves and measurement of their peak heights occurring at $255-265^{\circ} \mathrm{C}$. The TL glow curves were recorded using the reader/analyser, model RA'94 (produced by Mikrolab Kraków) equipped with a filter BG-28 (360-510 nm). Multiple-aliquot regenerative technique was used (Wintle and Prószyńska, 1983). For this purpose, the bleached material was divided into 5 equal portions. The first portion was used to measure the residual thermoluminescence, while the remaining ones were irradiated using the Co-60 source $(N T L+U V+\gamma)$ at Warsaw University of Life Sciences. This irradiation aimed at regeneration of the en- 


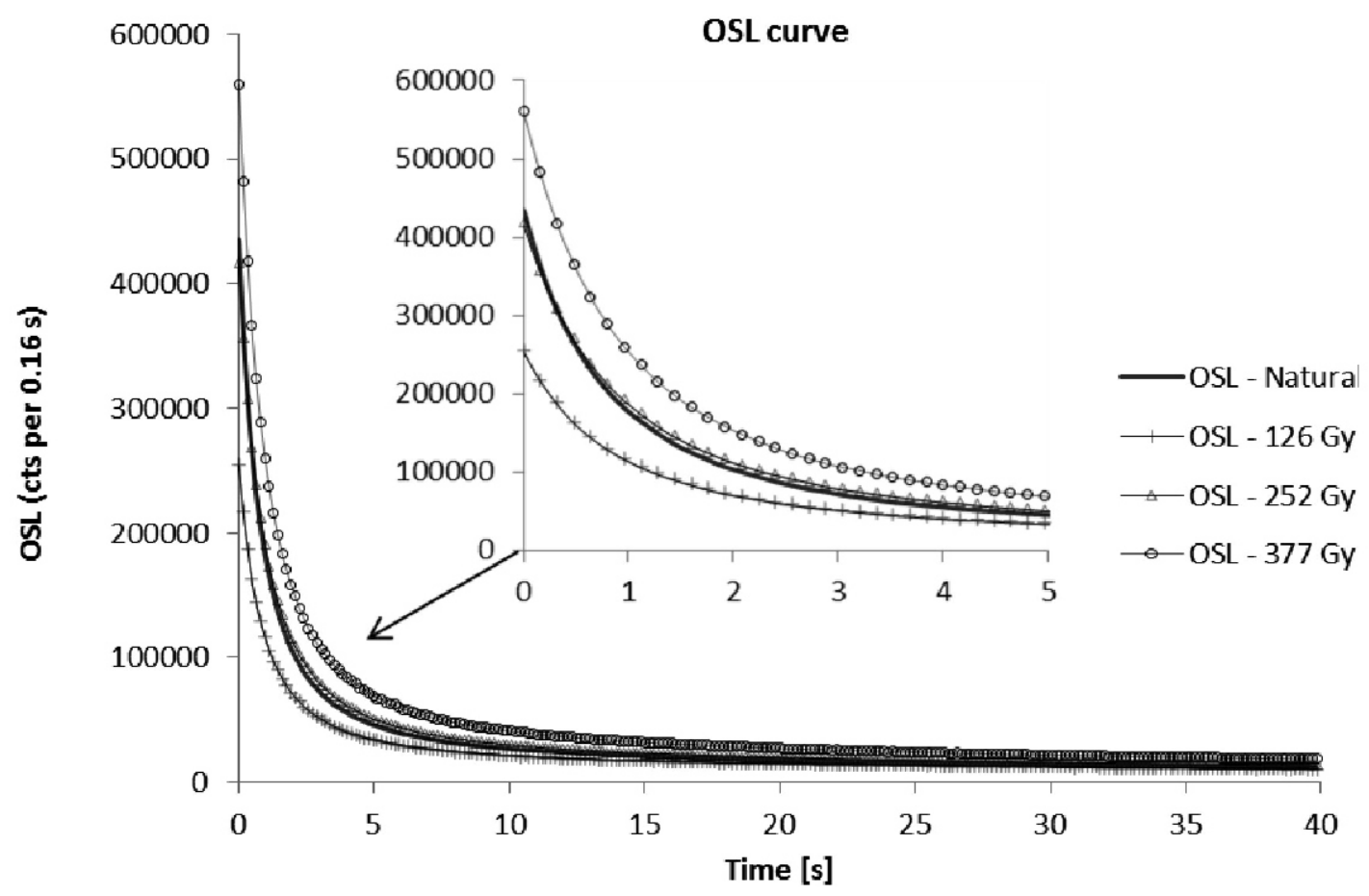

Fig. 5. An example of OSL shine-down curve for quartz (sample W-13, Lublin laboratory)

ergy acquired previously by the examined grains after bleaching (values from 20 to 100 Gy for younger samples, and from 20 to $300 \mathrm{~Gy}$ for older samples).

Five-milligram weighed samples were heated in argon atmosphere to $400^{\circ} \mathrm{C}$ with the heating rate of $3^{\circ} / \mathrm{sec}$ (Fig. 6). For each six-grain portion (one - NTL, one - NTL+ UV, and four $\mathrm{NTL}+U V+\gamma$ ) several glow curves were obtained after pre-heating at $230^{\circ} \mathrm{C}$ for $60 \mathrm{~s}$ (Van den Haute et al., 2003). The uncertainty of equivalent dose rate $\left(d_{e}\right)$ determination was about $10 \%$. Glow courves of all dates had a plateau. For all samples, the same area under the temperature of $240-320^{\circ} \mathrm{C}$ was used.

\section{RESULTS AND DISCUSSION}

The luminescence ages obtained for the Volochysk profile are the result of inter-laboratory research conducted in three Polish laboratories and should be analysed on several levels. We can only compare the dating results obtained for the same material in the individual laboratories, as well as relate them to the stratigraphy of the profile based on its litho- and pedological diversity. It would be also interesting to compare the dating results of the Volochysk profile with those obtained for stratigraphically similar horizons of loess profiles in adjacent regions.

\section{INTER-LABORATORY COMPARISON OF THE CONCENTRATIONS OF ${ }^{226} \mathrm{Ra}\left({ }^{238} \mathrm{U}\right),{ }^{232} \mathrm{Th}$ and ${ }^{40} \mathrm{~K}$ ISOTOPES}

Luminescence dating results obtained for the same sample in individual laboratories depend on many variables. According to the accepted procedures, each of the three laboratories used a different method of pre-treatment of samples, equipment, reagents, and measurement method. For the Volochysk profile, five different fractions of quartz or polymineral grains were dated, i.e. the $80-100 \mu \mathrm{m}$ and $90-125 \mu \mathrm{m}$ quartz grains, and the 4-11 $\mu \mathrm{m}, 45-56 \mu \mathrm{m}$ and 45-63 $\mu \mathrm{m}$ polymineral grains (Appendix 1). Given the above data, it can be concluded that one can directly compare only the concentrations of $\mathrm{U}$, Th and $\mathrm{K}$ radioisotopes, which are measured to determine the dose rate.

Spectrometric measurements of ${ }^{226} \mathrm{Ra}\left({ }^{238} \mathrm{U}\right),{ }^{232} \mathrm{Th}$ and ${ }^{40} \mathrm{~K}$ concentrations were performed in the Gliwice (Appendix 2), Lublin (Appendix 4) and Gdańsk (Appendix 5) laboratories. In 2014, the Lublin laboratory dated the same material that was previously analysed in the Gdańsk laboratory in 2011. The measurements were performed using the same type of three-channel gamma-ray spectrometer (MAZAR-95). The concentrations of $\mathrm{Ra}$, Th and $\mathrm{K}$ radionuclides, calculated in both laboratories, are overwhelmingly consistent and are within the limits of uncertainty. Discrepancies appear almost exclusively in the samples taken from the ice-wedge cast (samples from W-15 to W-18; Appendicies 4 and 5). The Gliwice laboratory, equipped with the most modern measuring device (high-resolution gamma spectrometer with an HPGe detector), obtained the results with the smallest uncertainty (Appendix 2 ). Inter-laboratory (Gdańsk-Gliwice) comparisons of the measurement results of radionuclide concentrations were already made for loess deposits a few years ago (Poręba and Fedorowicz, 2005).

The comparison of concentrations measured for 11 samples in three laboratories indicates that the results obtained for $\mathrm{Ra}(=\mathrm{U}$ in Gliwice) and Th are very consistent. The measured concentrations of $\mathrm{K}$ are higher in the Gliwice laboratory and exceed the limits of uncertainty, also for the deposits filling the ice-wedge cast. Since the measured radionuclide concentrations are the starting point for the calculations of dose rate, the above-escribed differences are certainly the reason that the dose rate value calculated in the Gliwice laboratory is higher than those obtained in the Lublin and Gdańsk laboratories.

However, taking into account the above-mentioned methodological assumptions of luminescence analyses, we find that the comparisons of dose rate values or equivalent dose values are not justified. 
Litho-

\begin{tabular}{|c|c|c|c|c|c|c|}
\hline & ì & TL age (ky) & OSL a & ge (ky) & post-IR & RSL (ky) \\
\hline & $\stackrel{\circ}{\check{1}}$ & Gdańsk & Lublin & Gliwice & Gliwice & Lublin \\
\hline & $\frac{\bar{N}}{\mathbb{N}}$ & $80-100 \mu \mathrm{m}$ & $45-63 \mu \mathrm{m}$ & $90-125 \mu \mathrm{m}$ & $4-11 \mu \mathrm{m}$ & $45-56 \mu \mathrm{m}$ \\
\hline & 1 & $18.6 \pm 2.6$ & $15.9 \pm 1.0$ & & & $29.0 \pm 2.0$ \\
\hline & $\begin{array}{l}2 \\
3 \\
4\end{array}$ & $\begin{array}{l}20.6 \pm 2.6 \\
24.1 \pm 3.6\end{array}$ & $\begin{array}{l}18.7 \pm 1.7 \\
17.3 \pm 0.9\end{array}$ & $\begin{array}{l}23.5 \pm 1.5 \\
53.8 \pm 4.0\end{array}$ & & $\begin{array}{l}29.8 \pm 2.3 \\
27.3 \pm 1.5 \\
\end{array}$ \\
\hline & 5 & $24.3 \pm 3.8$ & $19.0 \pm 2.1$ & $23.0 \pm 1.5$ & & $29.9 \pm 1.9$ \\
\hline & 6 & $42.8 \pm 6.3$ & $41.3 \pm 2.1$ & $24.0 \pm 1.6$ & & $63.9=4.2$ \\
\hline & 7 & $\begin{array}{l}43.9 \pm 5.9 \\
85.8 \pm 9.6\end{array}$ & $\begin{array}{l}44.2 \pm 2.9 \\
53.9 \pm 2.7\end{array}$ & $38.8 \pm 3.4$ & $\begin{array}{l}38.4 \pm 2.4 \\
55.0 \pm 3.2\end{array}$ & $\begin{array}{l}84.9 \pm 1.2 \\
84.9 \pm 1.2\end{array}$ \\
\hline & 10 & $\begin{array}{l}132 \pm 20 \\
109 \pm 16\end{array}$ & $\begin{array}{l}57.9 \pm 3.3 \\
65.8 \pm 3.5\end{array}$ & $56.4 \pm 4.6$ & $67.0 \pm 4.1$ & $\begin{array}{l}110 \pm 9 \\
124 \pm 11\end{array}$ \\
\hline & 11 & $127 \pm 18$ & $81.7 \pm 5.0$ & $67.3 \pm 5.7$ & $82.5 \pm 4.9$ & $166 \pm 9$ \\
\hline & $\begin{array}{ll}0 & 12\end{array}$ & $170 \pm 28$ & $92.3 \pm 6.2$ & $85.1 \pm 6.9$ & $94.4 \pm 5.6$ & $166 \pm 15$ \\
\hline & 0 & $167 \pm 26$ & $85.7 \pm 6.4$ & & & $166 \pm 10$ \\
\hline & 14 & $179 \pm 25$ & $85.0 \pm 5.0$ & $92.1 \pm 7.5$ & $97.0 \pm 5.7$ & $169 \pm 12$ \\
\hline
\end{tabular}

Loess-soil

stratygraphy

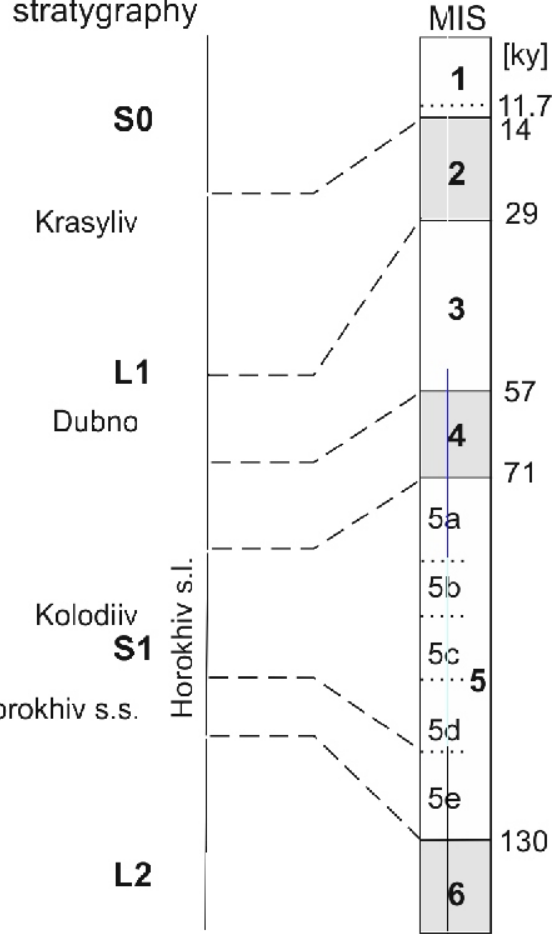

Fig. 6. Volochysk profile - lithology, stratigraphy and list of luminescence dating results

LUMINESCENCE AGES IN RELATION TO THE RESULTS OF GEOLOGICAL INVESTIGATIONS

Loess-soil sequence. The obtained luminescence ages were related to the results of local geological investigations. The lowest layer, which is accessible to research in the profile, is $\sim 1 \mathrm{~m}$ thick carbonate loess $\mathrm{L} 2$ containing $75.6 \%$ of silt and $8.3 \%$ of sand $(>63 \mu \mathrm{m})$. Its bottom part is massive and contains up to $15 \%$ of carbonates (sample W-14), and its upper part (samples $\mathrm{W}-13$ and $\mathrm{W}-12$ ) is characterized by a higher content of carbonates (up to $20 \%$ ) and the occurrence of numerous bioturbation forms (Fig. 3).

The dating results obtained in the Gliwice laboratory for the 4-11 $\mu \mathrm{m}$ polyminerals using the post0IR IRSL method (W-14: $97.0 \pm 5.7 \mathrm{ky} ; \mathrm{W}-12: 94.4 \pm 5.6$ ) and for the $90-125 \mu \mathrm{m}$ quartz grains using the SAR OSL method (W-14: $91.9 \pm 7.5 \mathrm{ky}$; W-12: $84.9 \pm 6.9 \mathrm{ky}$ ) were similar to the results obtained in the Lublin laboratory using the SAR OSL method (W-14: $85.0 \pm 5.0 \mathrm{ky}$; W-13: $85.7 \pm 6.4 \mathrm{ky}$; W-12: $92.3 \pm 6.2 \mathrm{ky}$ ). The same samples were also dated using the post-IR IRSL method in Lublin (W-14 $169 \pm 12 \mathrm{ky}$; W-13: $166 \pm 10 \mathrm{ky}$; W-12: $166 \pm 15 \mathrm{ky}$ ), and using the TL method in Gdańsk (W-14: $179 \pm 25$ ky; W-13: $167 \pm 26$ ky; $W-12: 170 \pm 28 \mathrm{ky}$ ). Undoubtedly, the results obtained for the finest fractions are underestimated by $\sim 80$ ky (Fig. 6). Similar underestimation of the OSL ages was found earlier for loess L2 in other Ukrainian profiles (Łanczont et al., 2011; Fedorowicz et al., 2013; Gozhik et al., 2014), as well as in Romanian (Timár-Gabor et al., 2011), and Chinese (Chapot et al., 2012) profiles. This underestimation resulted from the fact that the determined values of equivalent dose $\left(d_{e}\right)$ were considerably lower than the expected values, even by $\sim 150$ Gy (Chapot et al., 2012).

Soil S1 is the Horokhiv bipartite pedocomplex (Fig. 2B, D and F). Its older, Eemian (Horokhiv s.s.) part developed during the substage $5 \mathrm{e}$, and is represented by horizon $\mathrm{B}$, which is com- posed of clayey silt, and rich in the traces of pedofauna activity. The younger part of pedocomplex S1 is the Kolodiiv chernozem (terminology after Bogucki and Łanczont, 2002). This soil, which developed in the warmer phases of Early Vistulian (MIS $5 \mathrm{c}-5 \mathrm{a}$ ), is also rich in the traces of pedofauna activity, and disturbed by solifluction. The whole pedocomplex is cut by quite deep fissures filled with humus and mineral material. Three samples were taken from soil $\mathrm{S} 1$ for luminescence dating: W-11, W-10 and W-9 (Figs. 2F and 6) - the lowermost sample represents the Eemian Interglacial. In 2014, these three samples were dated in the Lublin laboratory using the SAR OSL method, and the obtained results were considerably different from each other (W-11: $81.7 \pm 5.0 \mathrm{ky} ; \mathrm{W}-10$ : $65.8 \pm 3.5 \mathrm{ky} ; \mathrm{W}-9$ : $57.9 \pm 3.3 \mathrm{ky}$; Appendix 4). In the Gliwice laboratory, two fractions (4-11 $\mu \mathrm{m}$ and $90-125 \mu \mathrm{m})$ separated from two samples (top and bottom ones) were dated. The following results were obtained: for fine polyminerals $-\mathrm{W}-11$ : $82.5 \pm 4.9 \mathrm{ky}$; W-9: $67.1 \pm 4.1 \mathrm{ky}$, and for coarse quartz grains - W-11: $67.3 \pm 5.7 \mathrm{ky} ; \mathrm{W}-9 ; 54.9 \pm 4.6 \mathrm{ky}$ (Appendix 2 ). The comparison of these dating results indicates that, for the same sample, the youngest ages were obtained for the coarsest fraction, and the difference between the extreme results was $\sim 20 \mathrm{ky}$. Moreover, all OSL dating results are underestimated in relation to the stratigraphy of the profile. Soil S1 is correlated with MIS 5 so it had to develop between 130 and $71 \mathrm{ky}$. The TL dating results (W-11: $127 \pm 18$ ky; W-10: $109 \pm 16$ ky; W-9: $132 \pm 20$ ky) fall into this time interval (Appendix 5). These TL ages are inverted, but the difference between the oldest and youngest age is simi$\operatorname{lar}(\sim 20 \mathrm{ky})$. The post-IR IRSL dating results obtained in Lublin (Appendix 3) are in stratigraphic order (W-11: $166 \pm 9 \mathrm{ky}, \mathrm{W}-10$ : $124 \pm 11 \mathrm{ky}$; W-9: $110 \pm 9 \mathrm{ky}$ ). The age of the bottom sample $(\mathrm{W}-11)$ is certainly overestimated; the other two results fall into the expected time interval. 


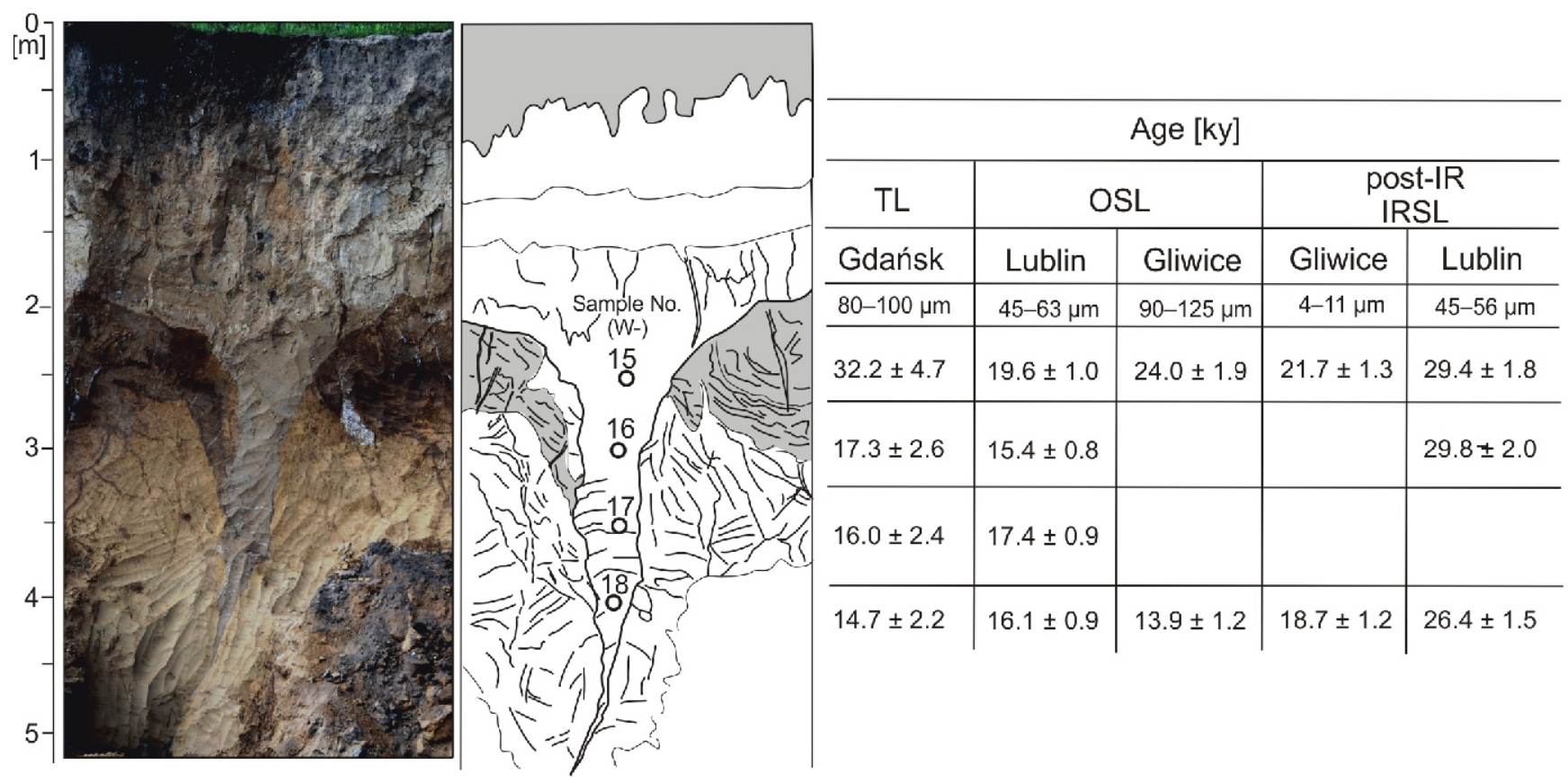

Fig. 7. Ice-wedge cast in the Volochysk profile - lithology and list of luminescence dating results

Eight luminescence dating results were obtained for $\sim 2 \mathrm{~m}$ thick loess L1, which was accumulated in the period from 71 to 14 ky (MIS 4-MIS 2). The loess layer has varied lithology and numerous traces of cryoturbation and solifluction. It contains the Dubno pedocomplex (well-developed, bipartite, interstadial soil), and the Krasyliv horizon (fossil active layer of permafrost, composed of sandy silt and enriched in secondary carbonates).

The bottom sample (W-8) of loess L1 was collected near its contact with soil S1. This sample was dated at $55.0 \pm 3.2 \mathrm{ky}$ $(4-11 \mu \mathrm{m}), 53.0 \pm 2.7 \mathrm{ky}(45-63 \mu \mathrm{m}), 84.9 \pm 1.2 \mathrm{ky}(45-56 \mu \mathrm{m})$, and $85.8 \pm 9.6 \mathrm{ky}(80-100 \mu \mathrm{m})$. The first two results seem to be slightly underestimated, and the other two - overestimated. These discrepancies can be explained by the influence of cryoturbation and by the fact that the sampled loess layer may contain an admixture of older grains from the underlying soil S1. Sample W-7 was taken from thin $(0.2 \mathrm{~m})$, but homogeneous, fawn loess underlying the Dubno pedocomplex. This sample was dated in Gliwice at $38.4 \pm 2.4$ ky $(4-11 \mu \mathrm{m})$ and $38.8 \pm 3.4 \mathrm{ky}(90-125 \mu \mathrm{m})$, in Lublin at $44.2 \pm 2.9 \mathrm{ky}(45-63 \mu \mathrm{m})$ and $84.9 \pm 1.2 \mathrm{ky}(45-56 \mu \mathrm{m})$, and in Gdańsk at $43.9 \pm 5.9 \mathrm{ky}$. All these results (except for the age obtained in Lublin for 44-56 $\mu \mathrm{m}$ ) are consistent and confirm homogeneity of this thin layer.

Samples W-6 and W-5 were taken from the Dubno unit. The finest fraction was not dated. The ages obtained for the $45-63 \mu \mathrm{m}$ grain size were $41.3 \pm 2.1 \mathrm{ky}$ and $19.0 \pm 2.1 \mathrm{ky}$, for $45-56 \mu \mathrm{m}-63.9 \pm 4.2 \mathrm{ky}$ and $29.9 \pm 1.9 \mathrm{ky}$, for $80-100 \mu \mathrm{m}-$ $42.8 \pm 6.3 \mathrm{ky}$ and $24.3 \pm 3.8 \mathrm{ky}$, for $90-125 \mu \mathrm{m}-24.0 \pm 1.6 \mathrm{ky}$ and $23.0 \pm 1.5 \mathrm{ky}$ for samples $\mathrm{W}-6$ and $\mathrm{W}-5$, respectively. These results, except for the $90-125 \mu \mathrm{m}$, reveal distinct age diversity between the lower and upper parts of the Dubno pedocomplex, which indicates that they developed in separate time intervals.

All dating results obtained for sample W- 5 indicate that the age of samples collected from the overlying layers should be $\sim 20$ ky or younger. This conclusion is confirmed by the results obtained for the 45-56 $\mu \mathrm{m}, 80-100 \mu \mathrm{m}$ and $90-125 \mu \mathrm{m}$ (except for the overestimated age of sample W-4), while the results obtained for the $45-56 \mu \mathrm{m}$ (samples from $\mathrm{W}-4$ to $\mathrm{W}-1$ ) using the post-IR IRSL method in Lublin are considerably overestimated.
Loess of the Krasyliv horizon was accumulated several thousand years ago (age of sample W-1).

Ice-wedge cast. The contemporary observations of ice-wedges in northeastern Siberia (where the ice-wedge width is 2-3 $\mathrm{m}$, and the distance between them 10-12 $\mathrm{m}$ ) indicate that they are formed under harsh climatic Arctic conditions and composed mainly of winter precipitation. The precipitation fallen in winter enters the ice-wedges as melt water in spring, and freeze (Gilichinsky et al., 2007).

In the Volochysk profile, cryogenic processes left a fossil system of epigenetic ice-wedges, which become narrow downwards (the wall probably intersects obliquely this structure). At a depth of $1 \mathrm{~m}$, the wedge is $1 \mathrm{~m}$ wide, at $2.2 \mathrm{~m}$ - only $0.2 \mathrm{~m}$, and further to a depth of $4 \mathrm{~m}$, it is a narrow and long fissure (Fig. 7). The contact between the ice-wedge cast and the layers it cuts is sharp, with visible micro-faults. Just below the top of ice-wedge cast, the surrounding material of horizon $A$ of the Horokhiv soil is deformed and curved upwards. Horizon B is less curved, but its deformations are also clearly visible near the fissure. This indicates that the studied structure was formed under active frost conditions, and the layers adjacent to the ice-wedge were squeezed (Jahn, 1977). The ice-wedge cast is filled with loess material, homogeneous, gleyed, enriched with iron compounds, medium compact, strongly carbonate, with carbonate concretions. In the bottom part, at a depth of 3.5-4 m (samples W-17 and $\mathrm{W}-18$ ), the material is horizontally laminated, which is accentuated by horizontal small fissures encrusted with carbonates. In the higher parts of the ice-wedge cast the material is oriented parallel to the walls of the form, and in its central part obliquely and vertically.

Four samples in a vertical series were taken at $0.5 \mathrm{~m}$ intervals from the material filling the ice-wedge cast, and in total 15 dating results were obtained for them. The luminescence ages decrease with depth so they are inverted. Except for the TL dates from Gdańsk and OSL dates from Gliwice (90-125 $\mu \mathrm{m}$ fraction), the results show a similar time span ( $\sim 3 \mathrm{ky})$ between samples $\mathrm{W}-15$ and $\mathrm{W}-18$. The TL and post-IR IRSL dating results are older than the rest. The post-IR IRSL ages obtained for the 4-11 $\mu \mathrm{m}$ (Gliwice) and 45-63 $\mu \mathrm{m}$ (Lublin) fractions are similar. For sample $W-15$, they are $21.7 \pm 1.3 \mathrm{ky}$ and $19.6 \pm 1.0 \mathrm{ky}$, 
and for sample $\mathrm{W}-18-18.7 \pm 1.2 \mathrm{ky}$ and $16.1 \pm 0.9 \mathrm{ky}$, respectively (Fig. 8). The youngest age (13.9 ky) was obtained for the infilling material taken from a depth of $4 \mathrm{~m}(90-125 \mu \mathrm{m}$; Gliwice).

Reasons for the discrepancies in dating results obtained for the samples taken from the ice-wedge cast can be seen in a probable heterogeneity of loess material. The width and length of the ice-wedge cast were known only in one plane, which probably intersected obliquely the structure. Therefore, its third dimension could not be determined. This parameter was probably varying spatially so the material collected in the probes could have been different.

\section{AN ATTEMPT TO COMPARE THE LUMINESCENCE DATING RESULTS OF LOESS DEPOSITS FROM THE VOLOCHYSK, KORSHIV} AND BOYANYCHI PROFILES

Volochysk and Korshiv profiles. The Volochysk and Korshiv (N part of the Volhynian Upland) profiles are situated $\sim 140 \mathrm{~km}$ apart. A significant number of luminescence dating results (82) were obtained for the Korshiv profile, which includes a sequence of loess layers and palaeosols correlated with MIS 7-MIS 2 (Fedorowicz et al., 2013). The comparison of loess and soil units and luminescence ages can be carried out only for the deposit sequences corresponding to the time interval from MIS 6 to MIS 2, which were investigated in both profiles (Fig. 8).

The samples from the Korshiv profile were dated in three laboratories using the following methods and fractions: Gdańsk

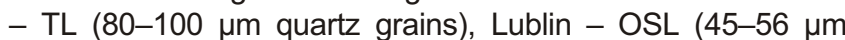
polyminerals), Gliwice - SAR OSL (90-125 $\mu \mathrm{m}$ polyminerals).

Loess L2 in the Korshiv profile was dated at $166 \pm 20$ ky to $132 \pm 16$ ky in the Gdańsk laboratory. Similar results were obtained in the Lublin laboratory (164 \pm 34 ky to $149 \pm 48 \mathrm{ky})$. The results from the Gliwice laboratory fall into the time interval from $104.5 \pm 4.6$ ky to $95.9 \pm 4.3$ ky (Fedorowicz et al., 2013).

The Horokhiv pedocomplex (MIS 5 ) is developed in the Korshiv site as the $1.5 \mathrm{~m}$ thick set of lessivé and chernozem soils. All the TL dating results obtained for this pedocomplex were older than the OSL ones, and they are characterized by age inversion (Fedorowicz et al., 2013). The beginning of the Horokhiv peodocomplex development is indicated by the following OSL ages: $81.7 \pm 5.0 \mathrm{ky}, 67.3 \pm 5.7 \mathrm{ky}, 82.5 \pm \mathrm{ka}$ (Volochysk profile), and $116.4 \pm 4.4$ ky (Korshiv profile). The end of this pedogenesis is indicated by the following OSL dating results: $57.9 \pm 3.3 \mathrm{ky}, 56.4 \pm 4.6 \mathrm{ky}, 67.0 \pm 4.1 \mathrm{ky}$ (Volochysk), and $53.0 \pm 2.3 \mathrm{ky}$ (Korshiv). The TL ages of the bottom of the pedocomplex are as follows: $127 \pm 18 \mathrm{ky}, 109 \pm 6 \mathrm{ky}$ (Volochysk), and 95.5 \pm 14 ky, $151 \pm 42$ ky (Korshiv) (Fedorowicz et al., 2013). The following TL ages were obtained for the top of the pedocomplex: $132 \pm 20 \mathrm{ky}, 86.0 \pm 4.5 \mathrm{ky}$ (Volochysk), and $68.9 \pm 9.3 \mathrm{ky}, 76.3 \pm 9.2 \mathrm{ky}$ (Korshiv). It can be considered that the data sets obtained for both profiles are generally similar. The vast majority of the dating results are within the time interval $130-70 \mathrm{ky}$. The OSL ages are distinctly underestimated. However, the period of the Horokhiv pedocomplex formation is well indicated by the difference between the results obtained for the underlying and overlying loess, which is $\sim 70 \mathrm{ky}$.

Loess L1 is $9 \mathrm{~m}$ thick in the Korshiv profile and contains three horizons of interstadial or interphase rank (Dubno, Rivne and Krasyliv). The bottom of loess L1 was OSL dated at $53.9 \pm 2.7 \mathrm{ky}$ and $55.0 \pm 3.2 \mathrm{ky}$ (Volochysk), and $38.9 \pm 1.7 \mathrm{ky}$ (Korshiv) (Fedorowicz et al., 2013), while the TL ages obtained for the same unit are $85.8 \pm 9.6$ ky (Volochysk), and $68.9 \pm 9.3 \mathrm{ky}$ and $76.3 \pm 9.2$ (Korshiv). Therefore, most OSL dating results are underestimated, and most TL ones are overestimated with respect to the expected ages. In both profiles, the bottom and top of the Dubno unit were dated. In the Volochysk profile, the dating results obtained for the bottom and top differ significantly. Thus, it can be assumed that the soil was formed in two stages: older $\sim 40 \mathrm{ky}$, and younger $\sim 25 \mathrm{ky}$. The TL ages obtained for the Korshiv profile indicate that the soil developed in one stage $\sim 40 \mathrm{ky}$. In both profiles, the age of the Dubno soil very well corresponds to the time interval of MIS 3

In the Korshiv profile, the top of loess L1 was dated at $\sim 14 \mathrm{ky}$, while in the Volochysk profile the dating results obtained for the uppermost sample (except for the OSL age from the Lublin laboratory) are considerably older. It is probable that the youngest loess in the Volochysk site has been preserved only in the bottom part of the ice-wedge cast.

Volochysk and Boyanychi profiles. The Volochysk and Boyanychi (NW part of the Volhynian Upland) sites are situated $180 \mathrm{~km}$ apart (Fig. 1B). In the Boyanychi site, two profiles exposed in the brickyard were investigated in 2007 and 2009. The profile studied in 2007 was dated in Gdańsk (Fedorowicz et al., 2008), and that investigated in 2009 - in Lublin (Kusiak et al. 2012). In both laboratories, the same types and size of mineral grains were used as in the case of the Korshiv profile. In total, 34 TL dating results were obtained. The bottom part of the older Korshiv soil was dated at $242 \pm 30$ ky (Gdańsk) and $268 \pm 62$ ky (Lublin). The top sample of loess L2 was dated at 143,2 $\pm 15 \mathrm{ky}$ (Gdańsk) and $145 \pm 19$ ky (Lublin). The TL dating results obtained for loess L2 in the Volochysk and Boyanychi profiles fall into the same time interval.

The TL dating results obtained for pedocomplex S1 in the Boyanychi site were from $126.8 \pm 14.2 \mathrm{ky}$ to $74.7 \pm 7.9 \mathrm{ky}$ (Gdańsk) and from $135 \pm 16$ ky to $101 \pm 13$ ky (Lublin), while the TL ages of pedocomplex S1 in the Volochysk profile fall into the time interval from $127 \pm 18$ to $85.8 \pm 9.6 \mathrm{ky}$ (Fig. 8).

The best material for comparison of dating results obtained for the Volochysk and Boyanychi profiles is loess L1 (Fig. 8). In loess deposits of the Boyanychi profile, like in the Korshiv profile, the following three units were distinguished: Dubno, Rivne and Krasyliv. One sample taken in 2009 from the Dubno unit was TL dated at $45 \pm 5.4 \mathrm{ky}$, and the samples taken from the underlying and overlying loess - at $55.3 \pm 6.6 \mathrm{ky}$ and $23.1 \pm 2.8 \mathrm{ky}$, respectively. In 2007 the Dubno unit was not dated, but the overlying loess was dated at $49.9 \pm 5.0 \mathrm{ky}$ in Gdańsk. The TL dating results obtained for the Dubno soil from both Boyanychi profiles are similar and fall into the time interval when the Glinde interstadial soil developed in Western Europe, i.e. from 51 to 44 ky (Frechen et al., 2001). Nine TL dating results, obtained for the deposits overlying the Dubno unit in the Boyanychi profile (2007), fall into the time interval from 23 ky to 16 ky (Kusiak et al., 2012). Similar results were obtained for the Volochysk profile.

\section{PALAEOGEOGRAPHIC INFERENCE}

The key to explain palaeoclimate problems are loess deposits, which are good material for luminescence dating, especially those with stratigraphically diverse and continuous vertical profile. Good examples of such application are the investigations conducted in several loess sites in Western and Central Europe (e.g., Antoine et al., 2001, 2009, 2013; Van den Haute et al., 2003; Moska et al., 2011, 2012, 2014; Moska and Bluszcz, 2013; Constantin et al., 2014). Inter-laboratory research experiments, aimed at finding the best methods of luminescence dating of loess, are less common. Such investigations were carried out for Belgian, Hungarian, Polish, Ukrainian and Czech loess deposits (e.g., Frechen et al., 1997, 1999, 2001; Bokhorst et al., 2011; Moska and Bluszcz 2013; Fedorowicz et al., 2013; Gozhik et al., 2014). 


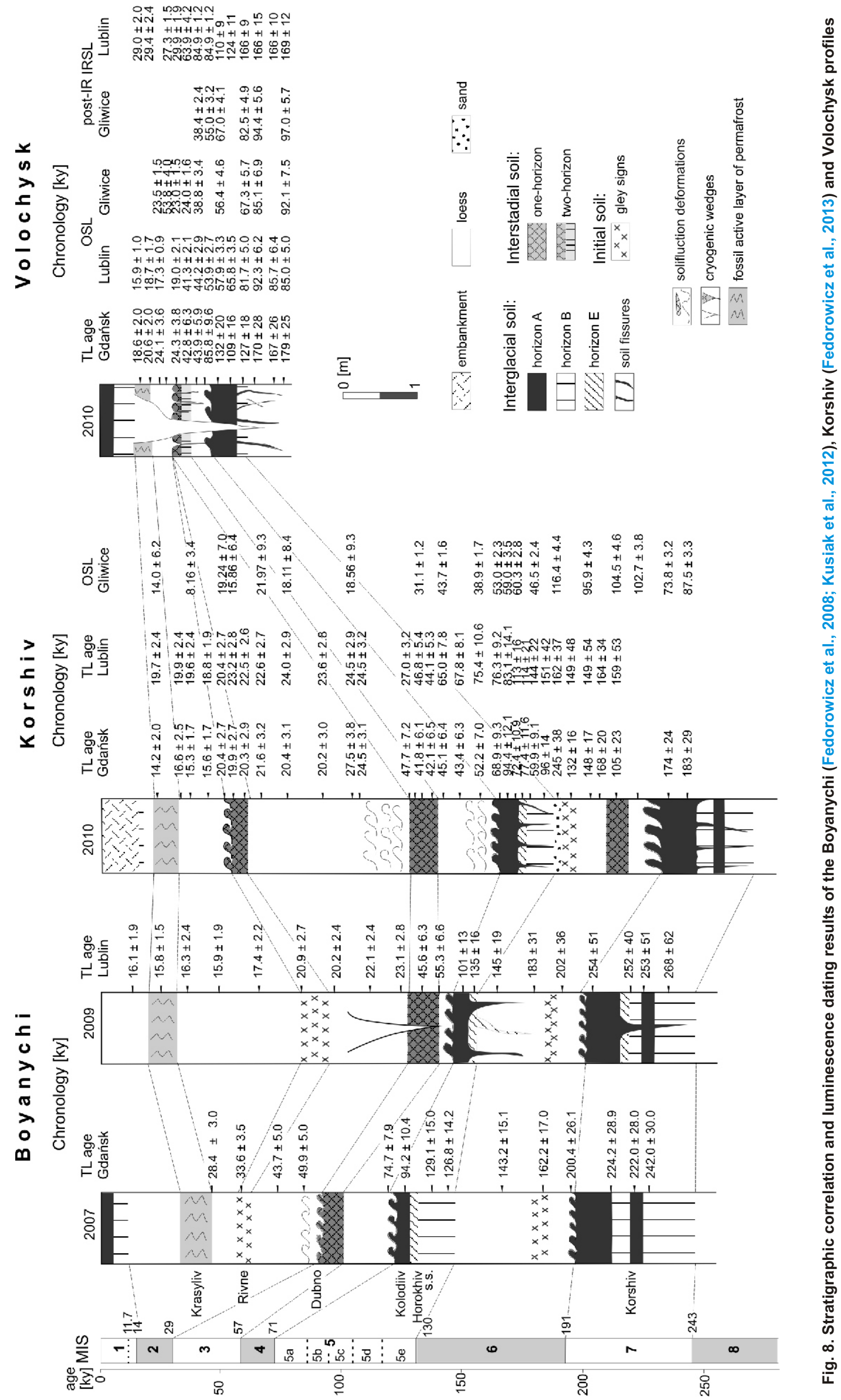


Analysis of all the dating results of the Volochysk profile shows that age inversion occurs only in several cases. Most of the luminescence ages obtained in each of the laboratories increase with depth. It is noteworthy that the TL ages of most samples are older than the OSL ones, irrespective of the size and type of dated grains. Moreover, in the whole analysed profile, the TL ages fall into the time interval of MIS 6-MIS 2, i.e. from $\sim 180$ ky to a dozen ky, while the OSL ages usually do not exceed $100 \mathrm{ky}$. However, underestimation of the OSL ages occurs only for the oldest samples - loess L2 and soil S1. In the Gliwice laboratory, the replacement of the 90-125 $\mu \mathrm{m}$ fraction with the 4-11 $\mu \mathrm{m}$ one and the SAR OSL with post-IR IRSL resulted in an increase of the obtained luminescence ages even by over $20 \%$ (Appendix 2 ), but the expected age (based on geological evidences) was not reached. The reasons for this have not been fully explained yet.

Age underestimation may be different. For example, in the Chinese Loess Plateau, the age of the finest fraction was underestimated for the samples older than 70 ky (corresponding to $\left.d_{e} \sim 230 \mathrm{~Gy}\right)$, and the samples with the expected age of $780 \mathrm{ky}$ (at the B/M boundary) were dated at $107 \mathrm{ky}$, which corresponds to $d_{e}=403 \mathrm{~Gy}$ (Lai and Fan, 2014). It was found that growth curves above 200 Gy are not linear and the signal for quartz is not stable. "The results show that, for the loess samples examined, quartz OSL does not fade anomalously, and the barrier age of $\sim 100 \mathrm{ky}$ is due to the fact that the OSL signals are less thermally stable, the lifetime of $0.311 \mathrm{Ma}$ at $20^{\circ} \mathrm{C}$ " (Lai and Fan, 2014).

Another example of a similar problem is the OSL dating of loess deposits correlated with MIS 5 from the Dobrogea profile (Romania). The dating results obtained for the 63-90 $\mu \mathrm{m}$ grain-size were older, even by $50 \%$, from those obtained for the 4-11 $\mu \mathrm{m}$ and 45-63 $\mu \mathrm{m}$ grain-size, which were similar (Timár-Gabor et al., 2011).

Similar problems in explaining the underestimation of older dating results were also mentioned by the researchers who dated samples of deposits other than loess. The SAR dating results obtained for fine fractions of the Eemian and older deposits from the Azzano Decimo site (northeastern Italy) were also underestimated. The authors stressed that the values of $d_{e}$ for all dating results obtained in the profile were within the linear part of growth curve. They were not able to give any reasons for this phenomenon (Lowick et al., 2010).

A dating experiment was conducted using samples of glacial deposits (correlated with MIS 5 and MIS 6) from Arctic Eurasia (Murray et al., 2007). The ages obtained by the SAR method were underestimated by $\sim 14 \%$ in relation to the expected ones. The same samples were then dated using the single aliquot regeneration and added (SARA) method. From a technical point of view, this method corrects any change in sensitivity, in contrast to the SAR method. The obtained SARA ages were older by $10-50 \%$ than the SAR ages, and confirmed the expected geological age of deposits. The samples, which were dated at $100 \mathrm{ky}$ by the SAR method, reached even $150 \mathrm{ky}$ when the SARA method was used, and thus they corresponded well to MIS 6 (Murray et al., 2007). The authors suggest that the problem of underestimation of luminescence ages can be solved by means of laboratory tests on the increase of quartz grain sensitivity. It seems that the SARA method (Murray et al. 2007) gives the opportunity to correct dating of the deposits correlated with MIS 5 and MIS 6.

From a palaeogeographic point of view, especially important dating results were obtained for the Dubno pedocomplex from the Volochysk profile. The Dubno unit developed during the period corresponding to MIS 3 (57-29 ky), which was characterized by unstable climatic conditions with frequent temperature and humidity fluctuations (Barron and Pollard, 2002; Van Andel, 2002; Alfano et al., 2003). Most dating results obtained for this pedocomplex fall within the mentioned time interval. The difference between the extreme results is $\sim 20 \mathrm{ky}$, i.e. much more than the uncertainty values, which confirms that the Dubno unit is bipartite in this site. Based on the luminescence dating results, it was found that the Dubno unit in other profiles of western Ukraine represents different parts of that long period (Nawrocki et al., 2003; Kusiak et al., 2012; Fedorowicz et al., 2013; Gozhik et al., 2014) - younger (Boyanychi in Volhynia), middle (Korshiv in Volhynia), older (Torchyn in Volhynia) - or the whole MIS 3 (Rivne in Volhynia; Maksymivka in the middle Dnieper River valley).

The problem of age and development of this soil unit is complex also in the case of loess deposits occurring in the rest of Europe. Soils corresponding to MIS 3 were dated in many other loess profiles, e.g. in Poland - Biały Kościół (Moska et al., 2011, 2012), Dybawka (Fedorowicz, 2006; Kusiak and Łanczont, 2013), Jaksice (Wilczyński et al., 2015; Łanczont and Mroczek, 2015); Kraków Spadzista (Łanczont et al., 2015a, b, c), Wilczyce (Łanczont et al., 2014) and Złota (Moska et al., 2014, 2015). A similar pedocomplex (Nussloch profile) in Lohner Boden (Germany) was radiocarbon dated at $30.5 \pm 0.7$ cal. ky BP (Antoine et al., 2001, 2009). Soil PKI in Bohemia was TL and IRSL dated at 30-36 ky and 40 ky (Frechen et al., 1999), and in Moravia (in the Red Hill site) it was OSL dated at 30.9-58.7 ky (Kis, 2012). In the Russian loess, there are several soils related to MIS 3 (Guidebook..., 2013; Sycheva and Khokhlova, 2016).

The set of the youngest luminescence dating results obtained for the Volochysk site gave a solution to the problem concerning the age of the youngest deposits (Fig. 8), i.e. loess (sample W-2) and the Krasyliv horizon (sample W-1). The post-IR IRSL age obtained in Lublin $(29.0 \pm 2.0 \mathrm{ky})$ is overestimated and considerably older that the TL $(18.6 \pm 2.0 \mathrm{ky}$; Gdańsk) and OSL (15.9 $\pm 1.0 \mathrm{ky}$; Lublin) ages. The mentioned dating results are also older than the luminescence ages of the corresponding horizons in the Volhynian profiles: Boyanychi -15 ky (TL, Lublin) (Kusiak et al., 2012) and Korshiv 14.2-15.3 ky (TL, Gdańsk), and even 14.0 ky (OSL, Gliwice) (Fedorowicz et al., 2013). These results allow the conclusion that the highest part of the loess cover in the Volochysk site has been probably eroded. However, we think that the luminescence dating results obtained for loess material filling the studied ice-wedge cast make a significant contribution to the discussion on the age of the youngest loess deposited in the Volochysk environs, and help to explain the inconsistency with the results from the Volhynian profiles. They also influence our conclusions about a complex way, in which the ice of the wedge has been replaced by mineral material. Based on the inversion of all obtained dates and horizontal lamination in the bottom part of the infilling, we may conclude that the degradation of ice-wedges started probably not with ice melting but at least partially with ice sublimation. A similar process was observed by A. Bogucki in the 1960s and 1970s in northwestern Siberia, characterized by very low temperature, thin snow cover, and great aridity. The age of the sample from the deepest part of the wedge seems to indicate that at first it was being filled with aeolian material. However, among five dates obtained for this sample, three are unreliable and indicate too old age (26-18.7 ky). The other three dates (between 13.9 and $16.1 \mathrm{ky}$ ) much better correspond to the above-mentioned dating results obtained for the Krasyliv horizon in the Volhynian and Podolian loesses, and are within the GS2a on the GICC05 timescale (Björck et al., 1988; Andersen et al., 2006). They indicate that the last stage of loess accumulation in the Podolian Upland probably corresponds to the younger part of the last glacial maximum, and to the youngest phase of the Scandinavian ice-sheet retreat in Central Europe - from land to the Baltic depression area (Marks, 2012). This period corresponds to the 
Heinrich event of $\mathrm{H} 1$, the age of which is determined at $\sim 16.8$ ky BP (Hemming, 2004) and 14 ky BP (Vidal et al., 1999). This problem certainly needs further study.

The next stages of ice-wedge degradation were characterized by ice melting. The ice was replaced by mineral material coming undoubtedly for the deposits cut by the wedge, and transported from its immediate surroundings, most probably due to flowing and creeping of unfrozen material during permafrost degradation. The fact that luminescence ages obtained for this material are inverted seems to confirm such process.

A successful attempt at dating of deposits from ice-wedge casts has been recently made by Remillard et al. (2015). They studied ice-wedge casts formed in the area abandoned by an ice sheet in the Magdalen Islands (Eastern Canada). Samples for luminescence dating were taken from four wedges. The obtained OSL dating results range from $9.8 \pm 0.7 \mathrm{ky}$ to $12.8 \pm 0.9 \mathrm{ky}$, which indicates the Younger Dryas as the period of development of those structures. These results confirm that the deposits filling ice-wedge casts are suitable for luminescence dating.

A significant contribution to the discussion on the problems with interpretation of luminescence age of loess deposits accumulated in MIS 2 was provided by Stevens et al. (2007) who analysed the TL dating results from the years 1980-2006 and the OSL dating results from the years 1990-2006, obtained for loess samples, using different methods and different fractions, especially the 4-11 $\mu \mathrm{m}$ polyminerals. The samples were taken at several sites of the Chinese Loess Plateau, from loess accumulated at the boundary between MIS 3 and MIS 2. The study area was described as a place of continuous deposition, so a uniform set of dating results falling within a short time interval should be expected. The authors stress that the TL ages were generally older than the OSL ones, and the latter were not uniform; the time interval in particular sites varied from 0.2 to $109 \mathrm{ky}$. This fact shows that the problem of interpretation of luminescence dating results is still far from being solved.

\section{CONCLUSIONS}

The Volochysk site, like the Boyanychi (Kusiak et al., 2012), Maximivka (Gozhik et al., 2014), Korshiv (Fedorowicz et al., 2013), Rivne and Torchyn (Nawrocki et al., 2003) sites, belongs to the Ukrainian loess-soil profiles, representative for this part of Europe, with the most complete set of luminescence dating results showing the age of distinguished units.

None of the luminescence methods and techniques used for the dating of samples taken from the Volochysk profile gave the results corresponding well to all time intervals of marine isotope stages. In this respect, the dating results obtained for the youngest loess L1 (accumulated in the period from MIS 4 to MIS 2) are the best, as they are comparable to each other irrespective of the method used.

So far, the Polish laboratories individually selected grain type and size for dating. This work on the dating of the samples from the Volochysk profile indicated the need to make changes and replace coarse grain with medium or fine grain. Such a replacement has been already made in the Gliwice laboratory where the finest polyminerals are dated. This change has brought good results, i.e. the obtained luminescence ages are older, especially those of older deposits (in it S1 and L2). The coarsest grains $(>80 \mu \mathrm{m})$ are present in loess in small quantities. It is also possible that they were transported before deposition over short distances, so they were exposed to sunlight for a shorter time than the finer grains. However, it is not a rule that, as in the Gliwice laboratory, the age obtained for finer grains (e.g., 4-11 $\mu \mathrm{m}$ ) is older than that obtained for coarser grains (e.g., 90-125 $\mu \mathrm{m}$ ).

The authors confirm the opinion that the grain-size fraction selected for dating should be dominant and most representative of the whole sample (Fedorowicz and Gaigalas, 2010). They suggest identifying, based on granulometric analysis, the dominant grain size in a sample before the start of dating procedure.

The OSL dating results obtained for older deposits (MIS 5 and MIS 6) are underestimated irrespective of the used method (post-IR IRSL or SAR OSL), type (quartz, polymineral) and size of grains. Numerous attempts were made to explain this phenomenon (among others, Timár-Gabor et al., 2011; Chapot et al., 2012), which, however, gave no answers. It was only found that this underestimation corresponded to the equivalent dose value of about $150 \mathrm{~Gy}$.

This work indicates that further research is necessary to improve the methods of luminescence dating of the deposits older than several tens of thousands years, so that the dating results could be helpful in solving chronostratigraphic problems. For this purpose, such discrepancies in dating results as those described in this paper should be excluded. We have no doubt that in the case of loess deposits with fine grains predominant (from $4-11 \mu \mathrm{m}$ to max. $63 \mu \mathrm{m}$ ) the dating procedure requires further methodological work. As loess is composed mostly of quartz, this work should concern the increase of quartz grain sensitivity. Does the SARA method give such opportunities? It is worthwhile to try this method on the samples of loess older than MIS 5, taken from thick and homogeneous layers with definite stratigraphic positions.

Acknowledgements. The study was carried out as part of the project No. NN306 474138 supported by the Ministry of Science and Higher Education. Granulometric analyses were performed using the analyser purchased under the Operational Program Development of Eastern Poland 2007-13. Priority Axis I: Modern Economy. Activity I.3. Support for innovation. "The growth of the R\&D potential of the Departments of Chemistry and Biology and Earth Sciences, Maria Curie-Skłodowska University in Lublin". We are very grateful to two anonymous reviewers whose comments and suggestions significantly improved the quality of this study. We especially wish to extend our deep gratitude to editors T.M. Peryt and W. Granoszewski.

\section{REFERENCES}

Adamiec, G., Aitken, M.J., 1998. Dose-rate conversion factors: update. Ancient TL, 16: 37-50.

Aitken, M.J., 1998. An Introduction to Optical Dating. Oxford University Press.
Alfano, M.J., Barron, E.J., Pollard, D., Huntley, B., Allen, J., 2003. Comparison of climate model results with European vegetation and permafrost during Oxygen Isotope Stage Three. Quaternary Research, 59: 97-107. 
Andersen, K.K., Svensson, A., Johnsen, S.J., Rasmussen, S.O., Bigler, M., Röthlisberger, R., Ruth, U., Siggaard-Andersen, M.L., Steffensen, J.P., Dahl-Jensen, D., Vinther, B.M. Clausen, H.B., 2006. The Greenland ice core chronology 2005, 15-42 ky. Part 1: Constructing the time scale. Quaternary Science Reviews, 25: 3246-3257.

Antoine, P., Rousseau, D.D., Zöller, L., Lang, A., Munaut, A.-V., Hatté, C., Fontugne, M., 2001. High-resolution record of the Last Interglacial-Glacial cycle in the Nussloch loess-paleosol sequences. Quaternary International, 76-77: 211-229.

Antoine, P., Rousseau, D.D., Moine, O., Kunesch, S., Hatté, C., Lang, A., Zöller, L., 2009. Evidence of rapid and cyclic eolian deposition during the Last Glacial in European loess series (Loess Events): the high-resolution records from Nussloch (Germany). Quaternary Science Reviews, 28: 2955-2973.

Antoine, P., Rousseau, D.D., Degeai, J.P., Moine, O., Lagroix, F., Kreutzer, S., Fuchs, M., Hatté, Ch., Gauthier, C., Svoboda, J., Lisá, L., 2013. High-resolution record of the environmental response to climatic variations during the Last Interglacial-Glacial cycle in Central Europe: the loess-palaeosol sequence of Doln Věstonice (Czech Republic). Quaternary Science Reviews, 67: 17-38.

Barron, E.J., Pollard, D., 2002. High-resolution climate simulations of Oxygen Isotope Stage 3 in Europe. Quaternary Research, 58 296-309.

Björck, S., Berglund, B., Digerfeldt, G., 1988. New aspects on the deglaciation chronology of South Sweden. Geographica Polonia, 55: 37-49.

Bluszcz, A., 2000. Luminescence dating of Quaternary sediments theory, limitations, interpretation problems (in Polish). Geochronometria, 17: 104.

Bogucki, A., 1972. Stratigraphy of loesses of the Volhynian Upland (in Polish). Guide-book of national symposium "Lithology and stratigraphy of loesses in Poland": 59-61. Wyd. Geol., Warszawa.

Bogucki, A., 1986. Antropogenovye pokrovnye otlozheniya Volyno-Podolii (in Russian). In: Antropogenovye otlozheniya Ukrainy: 121-132. Naukova Dumka, Kiev.

Bogucki (Boguckyj), A., 1987. Main loess and palaeosol horizons of the periglacial loess-palaeosol series of the south-western part of the East European platform (in Russian). In: Stratigrafiya i korrelatsiya morskikh i kontinentalnykh otlozhenii Ukrainy: 47-52. Naukova Dumka, Kiev.

Bogucki, A., 1990. Main paleocryogenic stages of Pleistocene in East European Platform (in Russian). Quaternary period, methods, stratigraphy and ecology, 1: 65-66.

Bogucki, A., Łanczont, M., 2002. Loess stratigraphy of Halyč Prydniestrov'ja region (in Polish with English summary). Studia Geologica Polonica, 119: 366-373.

Bogucki, A., Łanczont, M., 2011. The Korshiv profile compared to stratigraphic subdivisions of loesses in Europe. In: North Carpathian loess traverse in the Eurasian loess belt, abstract and field guide book (ed. Z. Jary ): 71-72. International Workshop - 6th Loess Seminar, Wrocław (Poland).

Bogucki, A.B., Łanczont, M., Łącka, B., Madeyska, T., Sytnyk O., 2009. Age and the palaeoenvironment of the West Ukrainian Palaeolithic: the case of Velykyi Glybochok multi-cultural site. Journal of Archaeological Sciences, 36: 1376-1389.

Bogucki, A., Voloshyn P., Tomeniuk, O., 2014. The collapsibility of Pleistocene loess-palaeosols and cryogenic levels in Volhynia and Podolia (in Polish with English summary). Przegląd Geologiczny, 62: 553-559.

Bokhorst, M., Vandenberghe, J., Sümegi, P., Łanczont, M. Gerasimenko, N.P., Matviishina, Z.N., Marković, S.B., Frechen, M., 2011. Atmospheric circulation patterns in centra and eastern Europe during the Weichselian Pleniglacial inferred from loess grain size records. Quaternary International, 234: 62-74.

Bortolot, V.J., 2000. A new modular high capacity OSL reader system. Radiation Measurements, 32: 751-757.

Bortolot, V.J., Bluszcz, A., 2003. Strategies for flexibility in luminescence dating: procedure-oriented measurement and hardware modularity. Radiation Measurements, 37: 551-555.
Chapot, M.S., Roberts, H.M., Duller, G.A.T., Lai, Z.P., 2012. A comparison of natural- and laboratory-generated dose response curves for quartz optically stimulated luminescence signals from Chinese Loess. Radiation Measurements, 47: 1045-1052.

Cohen, K.M., Gibbard, P.L., 2012. Global chronostratigraphic correlation table for the last 2.7 million years v. 2012. International Chronostratigraphic Chart 2012 - published for the International Commission on Stratigraphy, http://www.stratigraphy.org/upload/QuaternaryChart1.JPG

Constantin, D., Begy, R., Visiliniuc, S., Panaiotu, C., Necula, C., Codrea, V., Timar-Gabor, A., 2014. High-resolution OSL dating of the Costineşti section (Dobrogea, SE Romania) using fine and coarse quartz. Quaternary International, 334-335: 20-29.

Fedorowicz, S., 2006. Methodological aspects of luminescence dating of Central Europa's neopleistocene deposits (in Polish with English summary). Gdańsk University Press.

Fedorowicz, S., Gaigalas, A., 2010. Geochronological and sedimentological interpretation of interglacial aquatic sediments based on TL dating, Geochronometria, 35: 75-83.

Fedorowicz, S., Prylypko, S., Bogucki, A., Łanczont, M., 2008 Interlaboratory comparison of thermoluminescence (TL) ages of samples from the Boyanychi profile (Ukraine) (in Polish). In: Book of abstracts XV Konferencja „Stratygrafia plejstocenu Polski” Zakopane 1-5 September 2008: 92-95.

Fedorowicz, S., Łanczont, M., Bogucki, A., Mroczek, P. Adamiec, G., Bluszcz, A., Moska, P., 2012. Loess profile in the Podolia Upland (Wolochysk site on the Zbrucz River, Ukraine) preliminary results of natural and radiometric investigations (in Polish). In: Korelacja osadów plejstocenu na pograniczu polsko-niemieckim w dolinie dolnej Odry, XIX Konferencja „Stratygrafia plejstocenu Polski”, Cedynia 3-7.09.2012: 120-122.

Fedorowicz, S., Łanczont, M., Bogucki, A., Kusiak, J., Mroczek, P., Adamiec, G., Bluszcz, A., Moska, P., Tracz, M., 2013. Loess-palaeosol sequence at Korshiv (Ukraine) - chronology based on complementary and parallel dating (TL, OSL), and litho-pedosedimentary analyses. Quaternary International, 296: 117-130.

Frechen, M., Horváth, E., Gábris, G., 1997. Geochronology of Middle and Upper Pleistocene loess sections in Hungary. Quaternary Research, 48: 291-312.

Frechen, M., Zander, A., Cisek, V., Lozek, V., 1999. Loess chronology of the last interglacial/glacial cycle in Bohemia and Moravia, Czech Republic. Quaternary Science Reviews, 18: 167-1493.

Frechen, M., Van Vliet-Lanoë, B., Van den Haute, P., 2001. The Upper Pleistocene loess record at Harmignies/Belgium - high resolution terrestrial archive of climate forcing. Palaeogeography, Palaeoclimatology, Palaeoecology, 173: 175-195.

Folk, L.R., Ward, W.C., 1957. Brazos River bar: a study in the significance of grain size parameters. Journal of Sedimentary Petrology, 27: 3-26.

Gilichinsky, D.A., Nolte, E., Basilyan, A.E., Beer, J., Blinov, A.V., Lazarev, V.E., Kholodov, A.L., Meyer, H., Nikolskiy, P.A., Schirrmeister, L., Tumskoy, V.E., 2007. Dating of syngenetic ice wedges in permafrost with $36 \mathrm{Cl}$. Quaternary Science Reviews, 26: 1547-1556.

Gozhik, P., Komar, M., Łanczont, M., Fedorowicz, S., Bogucki, A., Mroczek, P., Prylypko, S., Kusiak, J., 2014. Paleoenvironmental history of the Middle Dnieper Area from the Dnieper to Weichselian Glaciation: a case study of the Maksymivka loess profile. Quaternary International, 334-335: 94-111.

Guidebook for Field Excursions, 2013. XIlth Symposium and Field Seminar on Paleopedology. Institute of Geography of Russian Academy of Sciences Press, Moscow.

Hemming, S.R., 2004. Heinrich events: massive late Pleistocene detritus layers of the North Atlantic and their global climate imprint. Reviews of Geophysics, 42: 1-43.

Jahn, A., 1977. Structures connected with ice wedges in Pleistocene deposits (in Polish with English summary). Studia Geologica Polonica, 52: 177-194.

Kis, E., 2012. Parallelization of Last Glacial loess-paleosol section of Red Hill with Heinrich events and ice core records. Hungarian Geographical Bulletin, 61: 327-341. 
Kukla, G.J., 1987. Loess stratigraphy in Central China. Quaternary Science Review, 6: 191-219.

Kusiak, J., Kanczont, M., 2013. Luminescence dating of the Dybawka Dolna profile on the San River middle terrace in the Carpathian marginal zone (Poland), testing of different procedures. 11th International Conference Methods of Absolute Chronology, May 15-18, 2013, Podlesice: 93.

Kusiak, J., Łanczont, M., Bogucki, A., 2012. New exposure of loess deposits in Boyanychi (Ukraine). Results of thermoluminescence analyses. Geochronometria, 39: 84-100.

Lai, Z., Fan, A., 2014. Examining Quartz OSL age underestimation for loess samples from Luochuan in the Chinese Loess Plateau. Geochronometria, 41: 57-64.

Lowick, S.E., Preusser, F., Pini, R., Ravazzi, C., 2010. Underestimation of fine grain quartz OSL dating towards the Eemian: Comparison with palynostratigraphy from Azzano Decimo, northeastern Italy. Quaternary Geochronology, 5: 583-590.

Łanczont, M., Madeyska, T., eds., 2015. Paleolityczna ekumena strefy pery- i metakarpackiej (in Polish). UMCS Press, Lublin.

Łanczont, M., Mroczek, P., 2015. Natural environment and palaeogeographical interpretation of the loess-soil sequence in the Jaksice II archaeological Gravettian site. Jaksice II. In: A Gravettian Site in Southern Poland: Jaksice II (ed. J. Wilczyński ): 1-18. ISEA PAN, Kraków.

Łanczont, M., Boguckij, A., Fedorowicz, S., Kusiak, J., 2011. Mesopleistocene loess deposits in the Mamalyha 2 profile of Ukraine - interlaboratory comparison of the thermoluminescence dating results. Geochronometria, 38: 350-358.

Łanczont, M., Mroczek, P., Zieliński, P., Hołub, B., Kusiak, J., Bałaga, K., Komar, M., Łącka, B., Żogała, B., Mendecki, M., 2014. Regional palaeogeographic analysis of the archaeological site and Opatówka river valley, and stratigraphic situation of the ice wedge cast. In: Wilczyce. A Late Magdalenian Winter Hunting Camp in Southern Poland (ed. R. Schild): 31-80. Instytut Archeologii i Etnologii PAN, Warszawa.

Łanczont, M., Madeyska, T., Mroczek, P., Hołub, B., Żogała, B., Bogucki, A., 2015a. Relief and palaeorelief analyses of the Kraków Spadzista Palaeolithic sites' complex as the tools used for explanation of the site location. Quaternary International, 359-360: 89-95.

Łanczont, M., Madeyska, T., Mroczek, P., Komar, M., Łącka, B., Bogucki, A., Sobczyk, K., Wilczyński, J., 2015b. The loess-palaeosol sequence in the Upper Palaeolithic site at Kraków Spadzista - a palaeoenvironmental approach. Quaternary International, 365: 98-113.

Łanczont, M., Mroczek, P., Madeyska, T., Komar, M., Bogucki, A., Żogała, B., Sobczyk, K., Wilczyński, J., 2015c. Natural environment of the Gravettian settlement in the Kraków Spadzista site based on palaeogeographical interpretation of loess-palaeosol sequences. In: A Gravettian Site in Southern Poland: Kraków Spadzista, (eds. P. Wojtal, J. Wilczyński and G. Haynes): 19-49. ISEA PAN, Kraków.

Marks, L., 2012. Timing of the Late Vistulian (Weichselian) glacial phases in Poland. Quaternary Science Reviews, 44: 81-88.

Matla, M., 2012. Lihology of loess sediments of profiles Korshiv and Wolotchisk (Ukraine). Unpublished typescript thesis of licentiate. Faculty of Geomorphology and Quaternary Geology of Gdańsk University.

Moska, P., Bluszcz, A., 2013. Luminescence dating of loess profiles in Poland. Quaternary International, 296: 51-60.

Moska, P., Adamiec, G., Jary, Z., 2011. OSL dating and lithological characteristic of loess deposits from Biały Kościół. Geochronometria, 38: 162-171.

Moska, P., Adamiec, G., Jary, Z., 2012. High resolution dating of loess profile from Biały Kościół, south-west Poland. Quaternary Geochronology, 10: 87-93.

Moska, P., Jary, Z., Adamiec, G., Bluszcz, A., 2014. OSL chronostratigraphy of a loess-palaeosol sequence in Złota using different dating methods. In: International Conference on Loess Research. In memoriam of George Kukla, September
8-9, 2014, Wrocław, Poland, loess in Poland: 6 day field trip, 10-15 September, 2014. Abstract \& field guide book (eds. Z. Jary and P. Mroczek): 38

Moska, P., Jary, Z., Adamiec, G., Bluszcz, A., 2015. OSL chronostratigraphy of a loess-palaeosol sequence in Złota using quartz and polymineral fine grains. Radiation Measurements, 81: 23-31.

Murray, A.S., Wintle, A.G., 2000. Luminescence dating of quartz using an improved single-aliquot regenerative-dose protocol. Radiation Measurements, 32: 57-73.

Murray, A.S., Svendsen, J.I., Mangerud, J., Astakhov, V.I., 2007. Testing the accuracy of quartz OSL dating using a known-age Eemian site on the river Sula, northern Russia. Quaternary Geochronology, 2: 102-109.

Nawrocki, J., Boguckyj, A., Łanczont, M., Kusiak, J., Werner, T., 2003. Palaeomagnetic principles of the chronostratigraphic division and correlation of the Vistulian loesses in the Volhynia Upland (in Polish). Materiały XII ukraińsko-polskiego seminarium terenowego „Stratygraficzna korelacja lessów i osadów lodowcowych Ukrainy i Polski" 15-19 września 2003, Sokil: 22.

Poręba, G., Fedorowicz, S., 2005. Gamma spectrometry for OSL and TL dating of leoss deposits at Dybawka and Tarnawce (SE Poland). Geochronometria, 24: 27-32.

Prescott, J.R., Hutton, J.T., 1994. Cosmic ray contributions to dose rates for luminescence and ESR dating: large depths and long-term time variations. Radiation Measurements, 23: 497-500.

Rémillard, A.M., Buylaert, J.-P., Murray, A.S., St-Onge, G., Bernatchez, P., Hétu, B., 2015. Quartz OSL dating of late Holocene beach ridges from the Magdalen Islands (Quebec, Canada). Quaternary Geochronology, 30: 264-269.

Stevens, T., Thomas, D.S.G., Armitage, S.J., Lunn, H.R., Lu, H., 2007. Reinterpreting climate proxy records from late Quaternary Chinese loess: a detailed OSL investigation. Earth-Science Reviews, 80: 111-136.

Sycheva, S., Khokhlova, O., 2016. Genesis, ${ }^{14} \mathrm{C}$ age, and duration of development of the Bryansk paleosol on the Central Russian Upland based on dating of different materials. Quaternary International, 399: 111-121.

Thiel, C., Buylaert, J.P., Murray, A., Terhorst, B., Hofer, I., Tsukamoto, S., Frechen, M., 2011. Luminescence dating of the Stratzing loess profile (Austria) - testing the potential of an elevated temperature post-IR IRSL protocol. Quaternary International, 234: 23-31.

Thomsen, K.J., Murray, A.S., Jain, M., Bøtter-Jensen, L., 2008. Laboratory fading rates of various luminescence signals from feldspar-rich sediment extracts. Radiation Measurements, 43: 1474-1486.

Timár-Gabor, A., Vandenberghe, D.A.G., Vasiliniuc, S., Panaoitu, C.E., Panaiotu, C.G., Dimofte, D., Cosma, C., 2011 Optical dating of Romanian loess: a comparison between siltsized and sand-sized quartz. Quaternary International, 240: 62-70.

Van den Haute, P., Frechen, M., Buylaert, J.P., Vandenberghe, D., de Corte, F., 2003. The Last Interglacial paleosol in the Belgian loess belt TL age record. Quaternary Science Reviews, 22: 985-990.

Van Andel, T.H., 2002. Reconstructing climate and landscape of the middle part of the last glaciation in Europe - The Stage 3 Project. Quaternary Research, 57: 2-8.

Vidal, L., Schneider, R.R., Marchal, O., Bickert, T., Stocker, T.F., Wefer, G., 1999. Link between the North and South Atlantic during the Heinrich events of the last glacial period. Climate Dynamics, 15: 909-919.

Wilczyński, J., Wojtal, P., Łanczont, M., Mroczek, P., Sobieraj, D., Fedorowicz, S., 2015. Loess, flints and bones - multidisciplinary research at Jaksice II Gravettian site (southern Poland). Quaternary International, 359-360: 114-130.

Wintle, A.G., Prószyńska, H., 1983. TL dating of loess in Germany and Poland. PACT, 9: 547-554. 